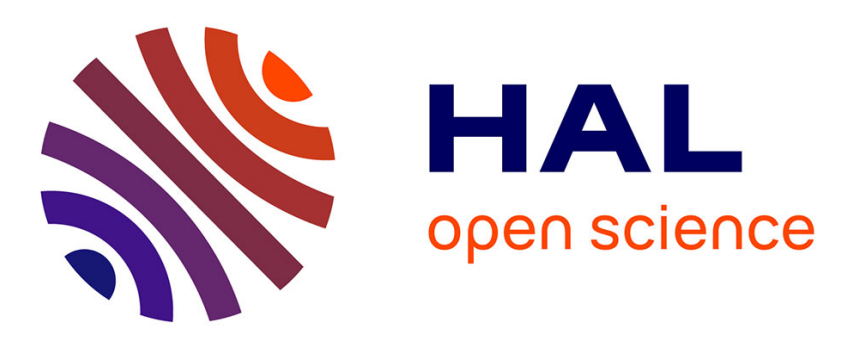

\title{
A fossil terrestrial fauna from Tobène (Senegal) provides a unique early Pliocene window in western Africa
}

Fabrice Lihoreau, Raphaël Sarr, Domininique Chardon, Jean-Renaud Boisserie, Renaud Lebrun, Sylvain Adnet, Jérémy Martin, Laurent Pallas, Bernard Sambou, Rodolphe Tabuce, et al.

\section{To cite this version:}

Fabrice Lihoreau, Raphaël Sarr, Domininique Chardon, Jean-Renaud Boisserie, Renaud Lebrun, et al.. A fossil terrestrial fauna from Tobène (Senegal) provides a unique early Pliocene window in western Africa. Gondwana Research, 2021, 99, pp.21 - 35. 10.1016/j.gr.2021.06.013 . hal-03413301

\section{HAL Id: hal-03413301 https://hal.science/hal-03413301}

Submitted on 3 Nov 2021

HAL is a multi-disciplinary open access archive for the deposit and dissemination of scientific research documents, whether they are published or not. The documents may come from teaching and research institutions in France or abroad, or from public or private research centers.
L'archive ouverte pluridisciplinaire HAL, est destinée au dépôt et à la diffusion de documents scientifiques de niveau recherche, publiés ou non, émanant des établissements d'enseignement et de recherche français ou étrangers, des laboratoires publics ou privés. 
Fabrice Lihoreau ${ }^{\mathrm{a}^{*}}$, Raphaël Sarr ${ }^{\mathrm{b}}$, Domininique Chardon ${ }^{\mathrm{c}}$, Jean-Renaud Boisserie ${ }^{\mathrm{d}, \mathrm{e}}$, Renaud Lebrun $^{\mathrm{a}}$, Sylvain Adnet ${ }^{\mathrm{a}}$, Jérémy E. Martin ${ }^{\mathrm{f}}$, Laurent Pallas d, Bernard Sambou ${ }^{\mathrm{b}}$, Rodolphe Tabuce $^{\mathrm{a}}$, Mohamadou M. Thiam ${ }^{\mathrm{g}}$ and Lionel Hautier ${ }^{\mathrm{a}}$

a Institut des Sciences de l'Evolution, UMR5554, CNRS, IRD, EPHE, Université de Montpellier, Montpellier, France <rodolphe.tabuce@umontpellier.fr> <sylvain.adnet@umontpellier.fr><renaud.lebrun@umontpellier.fr> <fabrice.lihoreau@umontpellier.fr><lionel.hautier@umontpellier.fr >

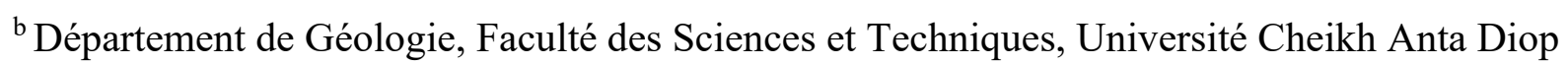
de Dakar, B. P. 5005 Dakar, Sénégal <mbundor52@yahoo.fr $><$ bradsam@live.fr $>$ ${ }^{\mathrm{c}}$ GET, Université de Toulouse, IRD, CNRS, UPS, CNES, Toulouse F-31400, France $<$ dominique.chardon@ird.fr>

d Palevoprim UMR 7262, CNRS, Université de Poitiers, France < jean.renaud.boisserie@univpoitiers.fr $><$ laurent.pallas@univ-poitiers.fr

${ }^{\text {e }}$ Centre Français des Études Éthiopiennes, USR 3137, CNRS, Ministère de l'Europe et des affaires étrangères, Addis Abeba, Éthiopie

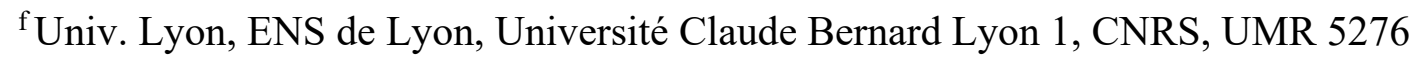

Laboratoire de Géologie de Lyon: Terre, Planètes, Environnement, F-69342 46 Allée d'Italie, Lyon, France jeremy.martin@ens-lyon.fr

${ }^{\mathrm{g}}$ Institut des Sciences de la Terre, Faculté des Sciences et Techniques, Université Cheikh Anta Diop de Dakar, B. P. 5005 Dakar, Sénégal $<$ Mohamadoumoustapha.thiam@ucad.edu.sn> 
*Corresponding author: <fabrice.lihoreau@umontpellier.fr $>$ Institut des Sciences de l'Evolution, cc 065 Université de Montpellier, place Eugène Bataillon 34095 Montpellier cedex 5

\section{ABSTRACT}

Early Pliocene hominin evolutionary scenarios proposed to date mostly rely on paleontological investigations from eastern Africa. Filling major geographical gaps in the fossil record could potentially invalidate these scenarios and stimulate development of improved theories. Based on published literature, no Pliocene fossil of continental vertebrates have been discovered in Western Africa and the situation is only slightly better in central and northern Africa. Here, we expand the Pliocene vertebrate continental fossil record to western Africa with the description of the Tobène fauna, a new fossiliferous Neogene locality from Senegal. We describe a diversity of large mammals, including at least ten taxa based on fragmentary remains recovered from alluvial channel deposits. Estimation based on weathering events and biochronology suggests an early Pliocene age. Most of these mammalian taxa were widely distributed over the African continent during the early Pliocene. Possible faunal correlations with eastern African localities call for continent-wide paleontological investigations.

Keywords: Neogene, vertebrate fauna, weathering events, fossil mammals. 


\section{Introduction}

Hypotheses on early hominins temporal and spatial distribution across Africa were formulated on the basis of geographically restricted paleontological data. The informal concept of "cradle of humankind" - repeatedly recognized in different regions- perfectly exemplifies how grey areas in the fossil record can bias our understanding of early human history. Although Pliocene localities are common and intensively surveyed in eastern and southern Africa (Werdelin, 2010), this time period remains poorly documented in the rest of the continent, notably in northern and central Africa (Arambourg, 1979; Brunet et al., 1995, 1998, 2000; Werdelin, 2010; Zouhri et al., 2017). Researchers however acknowledge important biases in the fossil record when proposing new biogeographic hypotheses or conceptual models (e.g. Joordens et al., 2019), especially the lack of vertebrate remains in western Africa for this time period. Outcrops exploitable for fossil discoveries are rare in this area, mostly due to Cenozoic lateritic weathering, vegetation, and the widespread Quaternary sand cover along the southern fringe of the Sahara (e.g., Michel, 1973; Beauvais et al., 2008).

Recent prospections undertaken as part of the PaleoSen project between 2012 and 2015 uncovered several vertebrate fossils in the Taïba Ndiaye quarry, Senegal (Fig. 1). Most of these remains were found in limestone deposits embedded in the Lutetian-Bartonian phosphate ore formation, and belonged to marine vertebrates (Hautier et al., 2012, 2014; Vautrin et al. 2019). Remains have also been excavated from the overlying continental deposits intercalated between the Eocene phosphate ore and the Quaternary sand cover in the Tobène pit of the Taïba Ndiaye quarry (Hautier et al., 2014).

This paper provides a description of the Tobène site, which hosts the only known Pliocene fauna from Senegal and well-beyond classical African Pliocene faunas, being 2,400 $\mathrm{km}$ distant from the nearest known Pliocene fossil site of Lissasfa, Morocco (Raynal et al., 1999) and Kossom Bougoudi and Kollé, Chad (Brunet et al. 1998, 2000) (Fig. 1). The Tobène 
locality, although poor in fossils relative to other Pliocene localities, is key to documenting the distribution of Pliocene ecosystems in Africa. Its age estimation was based on the combined study of biochronological markers and lateritic weathering events documented regionally and dated using geochronology (Beauvais et al., 2008). The taxonomic richness of the locality and the abundance of carnivorans is encouraging for future discoveries.

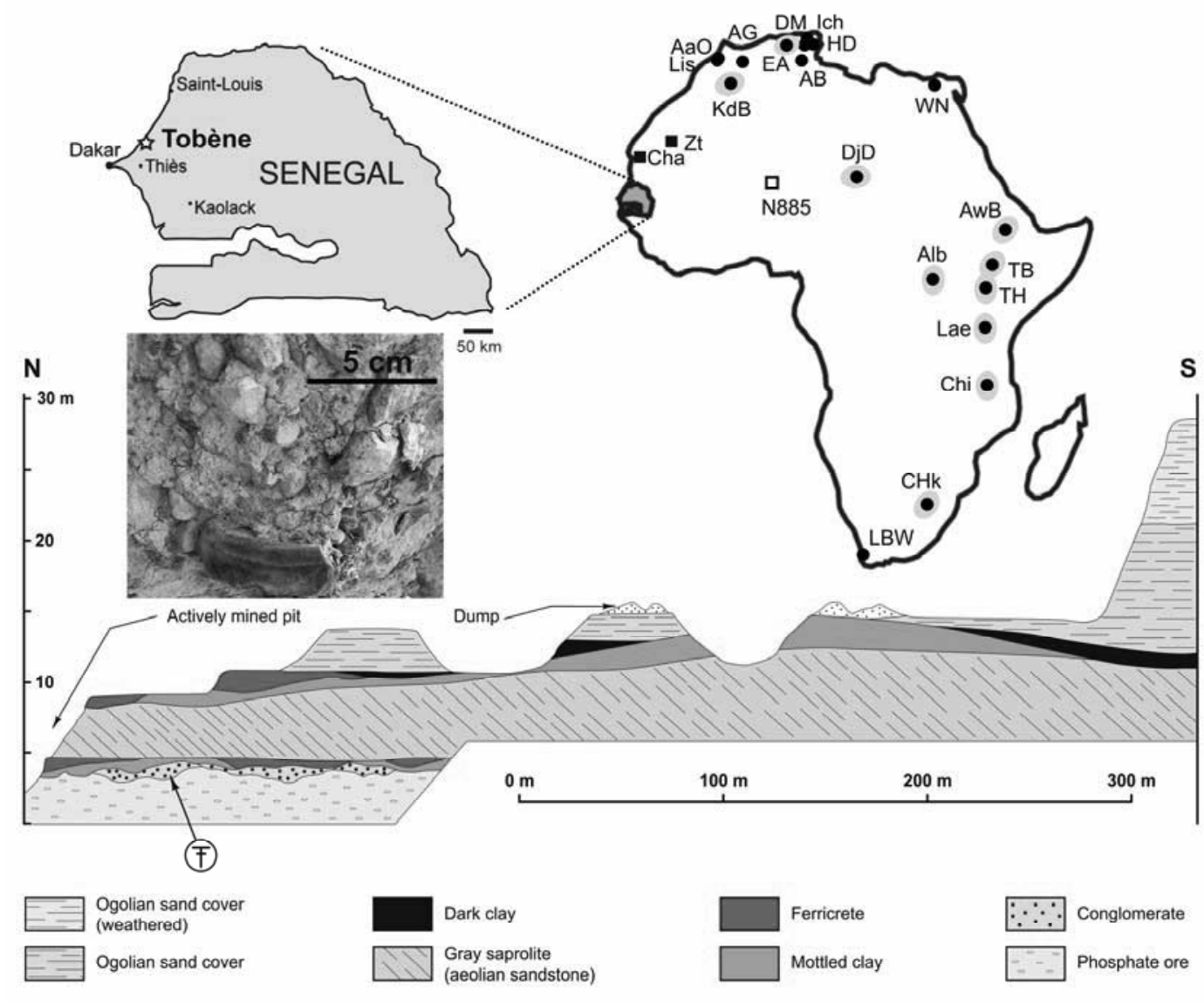

Fig. 1 [one and half column]. Location of the Tobène locality (Taïba Ndiaye Quarry), Senegal, with schematic cross-section of the southern part of the Tobène pit as exposed and investigated in November $2013\left(15^{\circ} 02^{\prime} 15^{\prime \prime} \mathrm{N} 16^{\circ} 48^{\prime} 40^{\prime \prime} \mathrm{W}\right)$. The photography shows a tooth remain of Deinotherium SN-Tob-12-03 in situ in the Pliocene conglomerate. The African map shows the main fossiliferous areas that have yielded Pliocene continental vertebrate faunas (black circle for isolated locality and grey circles for fossiliferous areas) and the western Neogene localities that have yielded continental vertebrates (black squares for holocene localities and white square 
for late Miocene locality). Abbreviations. AaO, Ahl al Oughlam; AB, Aïn Brimba; AG, Aïn Guettara; Alb, Albertine rift; AwB, Awash basin; Cha, Chami; Chi, Chiwondo; CHk, Cradle of Humankind; DM, Djebel Melah; DjD, Djurab desert; EA, Eastern Algeria; KdB, Aït Kandoula basin; HD, Hamada Damous; Ich, Garaet Ichkeul; Lae, Laetoli; Lis, Lissasfa; LBW, Langbaanweg; N885: N885 in Niger; TB, Turkana Basin; TH, Tugen Hills; WN, Wadi Natrun; Zt, Zouérate.

\section{Material and Methods}

\subsection{Geological context}

The PaleoSen project is a collaborative framework between Senegalese and French paleontologists from the University Cheikh Anta Diop of Dakar and the Institut des Sciences de l'Evolution of Montpellier. In addition to numerous field expeditions led in Senegalese Paleogene outcrops, three fieldtrips (2012, 2013, and 2015) focused on prospecting the upper part of the Tobène pit in the Taiba Ndiaye quarry, i.e., in strata overlying the exploited phosphate ore (Hautier et al., 2014).

During ore exploitation, miners usually extract calcareous blocks from the mined ore as well as blocks from the overlying sterile strata and store them in an open field. Blocks from the barren overburden are mostly made of conglomerates that have consistent sedimentological and petrological characteristics indicative of a common origin. The way the mining company operates for ore exploitation implies that a barren overburden stored area corresponds to a short period of exploitation in a specific part of the exploited open pit. Some of the conglomeratic blocks are fossiliferous (Fig. 1). They are all identified from a common stored area corresponding to one period of exploitation and thus the same mined pit. Detailed field 
investigations in the Tobène pit (cross-section in Fig. 1) indicate that the conglomerates directly and unconformably overly the phosphate ore. They are laterally discontinuous, suggesting emplacement in alluvial channels that have been partially eroded before sedimentary burial. The material is mostly a heterometric breccia made of reworked elements of the underlying ore, locally preserving a bedding and cross beds underlined by sand layers. Clasts may reach more than $20 \mathrm{~cm}$ in size. The most common unsorted and disorganized facies suggests debris flows, torrential and/or colluvial processes have fed the channels. Even if fossil specimens are generally broken, the different fragments are always spatially close to one another (e.g., femur SN-Tob-12-02), indicating a lack of transport after trapping in the sediments. Reworked fossils present in the conglomerates such as Lutetian sharks are easily recognizable by their whitish patina. Only a few conglomerate blocks present non-reworked vertebrate material. They share the same sedimentologic facies, suggesting a single sedimentary event at the origin of the fossil site of Tobène.

The conglomerates display various degrees of lateritic weathering and ferruginization, ranging from unconsolidated to a weakly to moderately indurated mottled clay facies (the "lateritoid" phosphate facies of former authors; Tessier, 1952; Pascal and Sustrac, 1989) or even an iron duricrust (ferricrete), in which only the largest clasts are still visible. Field observations indicate that the conglomeratic channels emplaced on a low-relief erosional land surface that developed a weathering profile (Fig. 1), which affected the conglomerates and their substrate. This resulted in a variety of weathering facies depending on the nature of the rocks exposed on the land surface at the time weathering took place (marine phosphate ore or the various overlying detrital materials making the conglomerate unit). This configuration explains the lateral variations in rock units as described/named by the miners in the upper parts of, or above, the main phosphate ore deposit at the scale of a given pit or among pits. 

sand cover (now sandstones) at least 6-m thick (Fig. 1). Steep oblique parallel stratification in the sandstones suggests an aeolian origin. This cover was then subjected to lateritic weathering. The sands were turned into a saprolite topped by a mottled clay horizon and, in the lower parts of the slightly undulating landscape, by a ferricrete. After a period of organic matter-rich clay sedimentation (dark clays), the weathered landscape was then buried under a thick ( $>15 \mathrm{~m})$ sand cover. The upper part of that sand cover was slightly weathered and acquired an orange/pinkish color. Those sands are known regionally as the Ogolian aeolian sands (Michel, 1973) deposited during the Last Glacial Maximum between 19000 and 15000 BP (e.g., Mulitza et al., 2008).

\subsection{Fossil materials}

Fossil remains were found embedded in the conglomerates extracted from the Tobène pit. Hereafter, the fossiliferous Pliocene locality will be designated as Tobène. Vertebrate remains consist of isolated postcranial and dental elements. The materiel is well preserved, not altered but often broken. It suggests a short but intense transport probably resulting from colluvial processes. Numerous vertebrate remains were excavated among which few are identifiable at a generic level. For mammals, all recognized taxa are represented by only one specimen each. The material is curated in the Geological Department of the University Cheikh Anta Diop of Dakar, Senegal. Material is numbered SN-Tob-year-number for "Senegal-Tobène". Three specimens were digitized using X-ray microtomography $(\mu \mathrm{CT})$ : the mandible SN-Tob-12-14, the canine SN-Tob-12-06, and the femur SN-Tob-12-02. The distal extremity of the femur contains four main fragments (the patellar groove, a part of the lateral condyle, the medial condyle, and a part of shaft), which were damaged and displaced post-mortem. 3D surfaces representing these four parts were extracted with Avizo 9.2 (Thermo Fisher Scientific). The 
four surfaces were positioned in space with MorphoDig software (Lebrun, 2018) in order to retrieve anatomical connection. The virtually restored 3D model of SN-Tob-12-02 has been deposited in MorphoMuseum (Lihoreau et al., in press).

Comparisons of this material were made with collections of extant mammals and fossils curated in Montpellier University (UM) in Montpellier, France, under the Authority for Research and Conservation of the Cultural Heritage (ARCCH) in Addis Abeba, Ethiopia, in the National Museums of Kenya (NMK) in Nairobi, Kenya, in the Centre National de la Recherche pour le Développement (CNRD) and in the Département de Paléontologie of N'Djamena University, both in N'Djamena, Chad.

\section{Systematic paleontology}

\subsection{Description of $c f$. Osteolaemus}

Class Reptilia Laurenti, 1768

Order Crocodylia Gmelin, 1789

Family Crocodylidae Cuvier, 1807

\section{cf. Osteolaemus}

\subsubsection{Studied material}

Several teeth, mostly of small size, were recovered and are represented by tooth crowns, the root being always broken off (Fig. 2A-J).

\subsubsection{Description}


One tooth is substantially larger (SN-Tob-13-07) with a preserved apico-basal length of $29 \mathrm{~mm}$.

187

188

189

190

191

192

193

194

195

196

197

198

Its enamel surface is poorly preserved but shows hints of longitudinal ridges over its labial and lingual surfaces. The tooth is conical, slightly curved lingually and bicarinate. The small teeth (SN-Tob-12-10, Fig. 2) are less than a centimeter in apico-basal length and show a distinct morphology with a somewhat bulbous crown. Ornamentation is variable and the enamel can be nearly smooth or marked by longitudinal ridges. In one specimen, the crown-root junction is preserved and is constricted as a collar (Figure 2E). In this specimen, the mesiodistal carinae are ornamented with irregular edges (Figure 2F).

This morphology resembles that of the distal tooth row of Osteolaemus. But contrary to this genus, they are not button shaped and the apex of the crown is pointed. The morphological variability in our sample most likely reflects tooth positions along the jaw, with mesialmost teeth being conical and distalmost teeth being blunter. Such a heterodonty is indeed most pronounced in Osteolaemus, which has bulbous distalmost teeth (compare with Plate I in Prasad and Lapparent de Broin, 2002). Crocodylus exhibits some degree of heterodonty too, with distal teeth retaining short crowns. The Tobène locality may have hosted both taxa but an unambiguous identification requires cranial elements or in the case of Osteolaemus, the very last distal teeth of the jaw.

Osteolaemus has been reported on the basis of skull and mandibular material from the Late (?) Miocene Sinda beds of NE Congo (Aoki, 1992), the Late Miocene of Uganda (Pickford, 1994) and from the Pleistocene (?) of Cabinda (Antunes, 1962). Considering the geographic range of the extant genus, encompassing Gambia and Senegal (Eaton, 2010), it would not be surprising to recover it in the fossil record of Senegal. Nevertheless, tooth morphology is poorly diagnostic and in the view of the high crocodylian diversity reported in Neogene localities across Africa 
210 particular taxon.
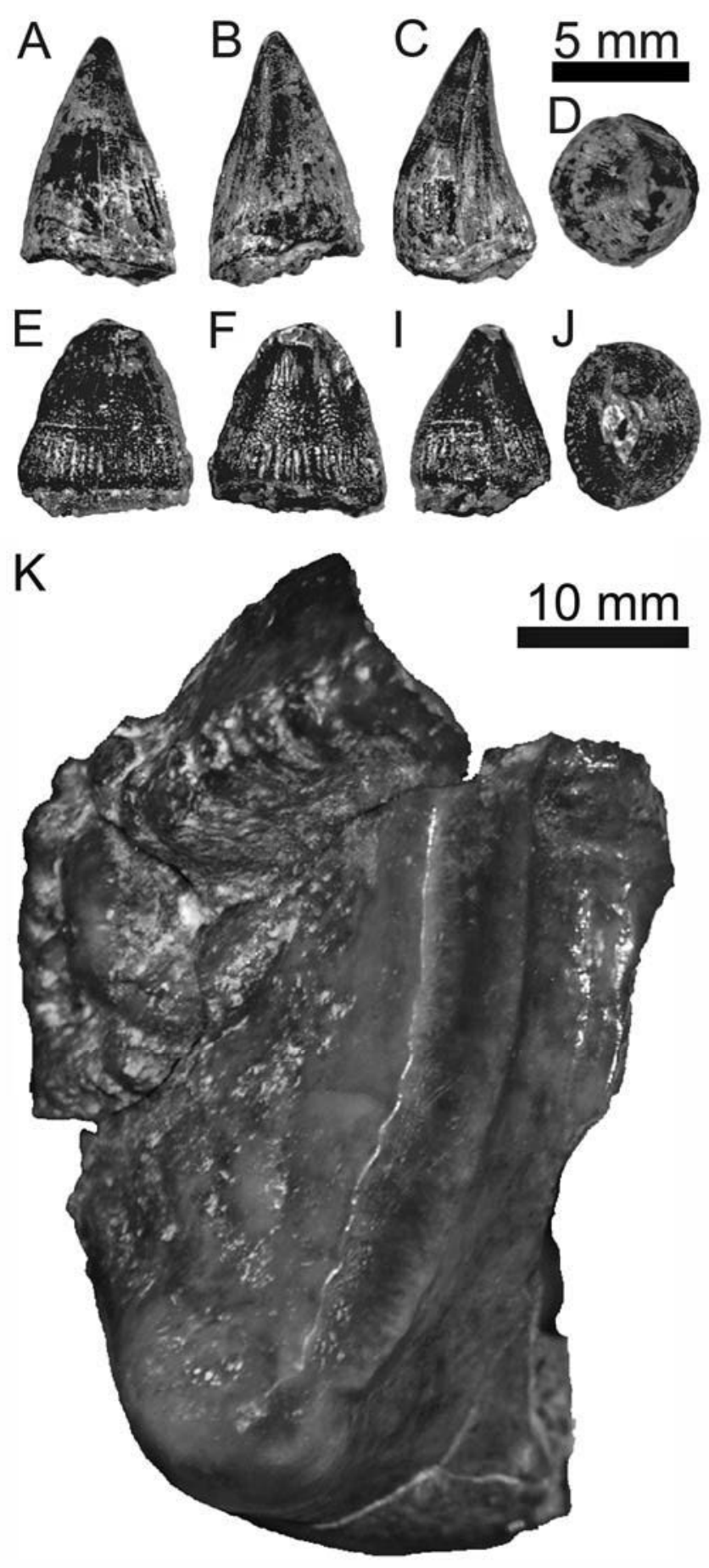

213 Fig. 2. [one column] Isolated teeth from Tobène. A-J: Teeth of Crocodylidae cf. Osteolaemus 214 (SN-Tob-12-10) in labial (A, E), lingual (B, F), distal (C, I) and apical (D, J) views. K: fragment 215 of metaloph and postmetaloph of a right M3/ (SN-Tob-12-03) of Deinotherium bozasi. 
Class Mammalia Linnaeus, 1758

Order Proboscidea Illiger, 1811

Family Deinotheriidae Bonaparte, 1845

Genus Deinotherium Kaup, 1829

223

Deinotherium bozasi Arambourg, 1934

\subsubsection{Studied material}

A right M3/ (SN-Tob-12-03; Fig. 2K) preserving the metaloph and postmetaloph.

\subsubsection{Description}

231

Right M3/ largely broken and worn, reduced to an incomplete metaloph concave distally (Width $233(\mathrm{~W})>60 \mathrm{~mm})$. The metacone is missing. The postmetacrista is long, crenulated, pointing 234 distomedially and terminating at the midline of the tooth. The distal cingulum is present and constituted of multiple conules of variable size. Concerning size differences (estimated by the width of the metaloph), the Tobène molar globally fits in the lower range of the M3/ from Omo Shungura Formation (Fm.) and Mursi Fm 238 in Ethiopia (pers. obs.; Drapeau et al., 2014: fig.3-2). Harris et al. (2003) looked at size 239 evolution in D. bozasi teeth from the Turkana Basin (i.e., Kanapoi, Kenya and Omo Group 
deposits), and proposed a temporal size gradient, with the oldest ones being smaller than those

241 from younger horizons. The large variation in size amongst contemporaneous sites of the Omo

242 Valley is similar to that observed in the whole temporal sequence of the Turkana basin, which

243 tends to partly contradict this hypothesis. The distal cingulum of the Tobène tooth has large and

244 crenulated postmetacrista and distal cingulum (Fig. 2K), which are variably developed among

245 specimens attributed to D. bozasi from the Omo valley (L876-1, L596-19, OMO 29-69-3087,

246 Kib-133-3).

247

248

3.3. Description of Nyanzachoerus $c f$. jaegeri

249

250 Class Mammalia Linnaeus, 1758

251 Order Cetartiodactyla Montgelard, Douzery and Catzeflis, 1997

252 Family Suidae Gray, 1821

253 Subfamily Tetraconodontinae Lydekker, 1876

254 Genus Nyanzachoerus Leakey, 1956

255

256

Nyanzachoerus cf. jaegeri

257

258

3.3.1. Studied material

259

260 Distolabial fragment of left P4/ metacone (SN-Tob-13-27, Fig. 3A-B).

261

262

\subsubsection{Description}

263 
This dental fragment is characterized by a relatively shallow crown (Fig. 3A) and thick enamel displaying (Fig. 3B) a fine wrinkling. These features suggest a suid and, more particularly due to wrinkled enamel (Fig. 3A), a tetracondontine. The cingulum, with a contact wear facet, is high and flattened. It fuses with the wall without reaching the cervix (Fig. 3A), which is curved and apically indented above the cingulum. These features match the morphology of a distolabial fragment of a left P4/.

In terms of size, SN-Tob-13-27 appears much larger than in observed specimens of Notochoerus from Hadar, Omo, and Middle Awash in Ethiopia (premolars are reduced in this genus), and the groove between the metacone and the paracone (Fig. 3B) is deeper in No. euilus. SN-Tob-13-27 is also larger than in early representatives of Nyanzachoerus (i.e., Ny. devauxi, Ny. waylandi, Ny. tulotos and Ny. Khinzir).

In Nyanzachoerus australis (e.g., AMH-VP 1/6 and KUS-VP 1/10 from the Middle Awash), the groove between the paracone and the metacone is also better expressed than in SN-Tob-1327. Ny. australis displays higher cusps and cingulum than in SN-Tob-13-27 at an equivalent wear stage, suggesting that the Tobène specimen might be smaller. In Ny. kanamensis from Hadar, the cingulum is thicker and not attenuated cervically.

Considering its size, its morphology as well as the oblique position and complicated shape of the metacone wear facet, SN-Tob-13-27 would be closer to specimens attributed to Ny. jaegeri (e.g., ARA-VP 16/1, SAG-VP 7/122, and GAW-VP 3/300 from the Middle Awash) than to any other observed tetraconodontine specimens. Unfortunately, the $\mathrm{P} 4 /$ is not preserved on the holotype of this species (Coppens 1971a). Keeping in mind that attributing an isolated tooth is difficult, even more so for such a fragmentary specimen, we tentatively propose an attribution to Nyanzachoerus cf. jaegeri.

\subsection{Description of cf. Giraffa sp. indet.}


Class Mammalia Linnaeus, 1758

291

292

\section{Order Cetartiodactyla Montgelard, Douzery and Catzeflis, 1997}

Suborder Ruminantia Scopoli, 1777

Family Giraffidae Gray, 1821

cf. Giraffa sp. indet.

\subsubsection{Studied material}

An ungual phalanx (SN-Tob-12-01, Fig. 3C-E) partially broken at its distal end.

\subsubsection{Description}

The ungual phalanx belongs to a large ruminant. Its dimensions (minimal length $(\mathrm{L})=92.8 \mathrm{~mm}$ and width $(\mathrm{W})=47.1 \mathrm{~mm}$ ) exceed those of large Bovidae such as Bos taurus and the largest known ungual phalanx of Bovidae from Omo and Hadar collections. Its size fits the range of extant Giraffa phalanges. Similarly, the morphology of SN-Tob-12-01 recalls Giraffidae rather than Bovidae, notably based on its general proportion (wider than high), the large dorsal part of the proximal facet with prominent dorso-lateral border, the wide distal part on dorsal and plantar views, and the wide and medial articular facet with the sesamoid that is narrower and more central in bovids (Fig. 3D). Unlike bovids, the plantar face is flat, wrinkled and significantly curved, with the distal part larger than the proximal one (Fig. 3C, E). Comparisons with ungual phalanges of fossil giraffids are difficult as this bone is rarely described and specific attribution remains hazardous. The third phalanx is of similar length in extant Giraffa, Giraffa 
cf. stillei from the Plio-Pleistocene of Omo, an unpublished giraffid from the late Miocene of

315 Toros-Menalla, Chad (TM242-02-03 in CNRD), Bohlinia cf. attica from the late Miocene of 316 Küçükçekmece in Turkey (Kostopoulos and Sen, 2016), and Decennatherium from the late 317 Miocene of Spain (Ríos et al., 2016). The dorso-medial process for the insertion of the toe 318 extensor muscle is more developed than in extant Giraffa.

Despite a large collection of giraffid from African Pliocene deposits (Harris et al., 2010), no comparison can be established for the third phalanx between Giraffa and Sivatherium, including the well-known Sivatherium giganteum (see Basu et al., 2016). However, the proportions of the phalanx, notably the plantar face and the angle between the plantar face and the articulation, suggest that it belongs to a less massive animal than Sivatherium spp, its size being congruent with Giraffinae. SN-Tob-12-01 resembles an indeterminate Giraffa specimen from Omo (OMO 66), both in size $(\mathrm{L}=90 \mathrm{~mm}, \mathrm{~W}=45 \mathrm{~mm})$ and morphology. We therefore propose the presence of cf. Giraffa in the Tobène locality.

327

\subsection{Description of $c f$. Simatherium demissum}

Class Mammalia Linnaeus, 1758

Suborder Ruminantia Scopoli, 1777

Family Bovidae Gray, 1821

334 Subfamily Bovinae Gray, 1821

335 Tribe Bovini Gray, 1821 


\subsubsection{Studied material}

Left mandible with fragmentary and worn P/4-M/1 and alveolus of P/3 (SN-Tob-12-14, Fig. 3I-J).

\subsubsection{Description}

The mandible belongs to a large Bovidae. The lower $\mathrm{P} / 4$ lacks its labial part and is strongly worn (Fig. 3I-J). The paraconid and metaconid are not fused and a central valley separates the two cuspids: this condition is known in Hippotragini and early Bovini such as Ugandax and Simatherium but is absent in most Tragelaphini, Alcelaphini as well as recent African Bovini, Pelorovis and Syncerus (Gentry, 2006). In Tragelaphini, the metaconid is always projected mesially even if some specimens lack a connection between the paraconid and metaconid. The metaconid is slanted backward and fused with the entoconid (Fig. 3I). The parastylid and paraconid are separated even if largely worn (Fig. 3I). This morphology recalls that of Simatherium demissum from Langebaanweg in South Africa (Gentry, 1980; Haile-Selassie et al., 2009). Alongside with the $\mathrm{P} / 4$ morphology, the large size of the mandible argues in favor of an early Bovini (Gentry, 1980; Fig. 3J). The Tobène specimen displays a long P/4 ( $\mathrm{L}=24$ $\mathrm{mm}$ ), which is larger than in most bovines except for the largest specimen of S. demissum from Langebaanweg, an indeterminate Bovini from the Apak Member, Lothagam in Kenya (LT24002; Harris, 2003), and a possible Simatherium from the Nkondo Formation, Uganda (NK771'88; Geraads and Thomas, 1994). As in the latter, the mesial valley of SN-Tob-12-14 remains open at the base of the crown (Geraads and Thomas, 1994).

The M/1 is largely broken and extremely worn; only the lingual wall remains visible. The mesowear is sharp and not blunt (Fig. 3J) as in derived Bovini. No cement is visible on the 
lingual margin, as in Simatherium demissum from Langebaanweg (Gentry, 1980) and Ugandax cf. gautieri from Lukeino, Kenya (Thomas, 1980). The mesostylid is incipient and the lingual valley is not marked. The remnants of the occlusal surface look simple with a flat lingual border compared to $U$. coryndonae from Hadar and other earliest Bovini. This configuration is due to the bad preservation of the Senegalese specimen because only its crown base is preserved. The $\mathrm{M} / 1$ is very long ( $\mathrm{L}>30 \mathrm{~mm})$; it is longer than $\mathrm{M} / 1$ of most known Bovini except the largest specimens of S. demissum from Langebaanweg (Gentry, 1980). Based on its root insertions, the molar seems to be more brachyodont than other known Bovini. The weak development of cuspid lingual ribs differs from most Bovini but recalls S. demissum from the basal Pliocene of South Africa, which is also weakly hypsodont.

Mandibular height below M/1 $(\mathrm{H}=50.5 \mathrm{~mm})$ is similar to $S$. cf. demissum from Kanapoi and Ugandax coryndonae from Hadar. Nevertheless, the few known occurrences of early Bovini do not allow estimating variation in range sizes. The mandibular height below diastema is not measurable due to fossil deformation (Fig. $3 \mathrm{~J}$ ). Lower premolar row length and diastema length in front of $\mathrm{P} / 2$ are considered to be more diagnostic (Geraads and Thomas, 1994). The maximum $\mathrm{P} / 2-\mathrm{P} / 4$ length in $\mathrm{SN}-\mathrm{Tob}-12-14$ could be estimated around $54 \mathrm{~mm}$, which is not different from early Bovini and even from the extant Syncerus cafer. The long diastema (close to $70 \mathrm{~mm}$ ) is remarkable, and is similar in length to that of $S$. demissum from Langebaanweg and S. aff demissum from Kanapoi. In Ugandax coryndonae, the diastema is short and systematically shorter than the premolar row length. It is also the case in a mandible from N'Kondo, which led Geraads and Thomas (1994) to propose its attribution to the genus Ugandax.

Diagnoses of early African Bovini are mainly based on skull and horn morphologies. Differences in the lower teeth of Simatherium and Ugandax are unclear, but dental variation is often poorly characterized in extinct bovine species due to the material scarcity (Gentry, 2010). 
389 The species Simatherium demissum has sometimes been attributed to the genus Ugandax 390 (Gentry, 2006, 2010; Bibi, 2011) but without clear consensus (Haile-Selassie et al., 2009; 391 Geraads et al., 2013; Geraads and Bobe, 2017). As a matter of consistency, we retain a 392 taxonomic attribution to Simatherium demissum pending future taxonomic revisions. The Tobène specimen appears as a plesiomorphic Bovini, considering the morphology 394 of its $\mathrm{P} / 4$ and the absence of cement on its molar. Following Gentry (2006), the large teeth of 395 the Senegalese specimen allow an attribution to early Bovini such as S. demissum from 396 Langebaanweg. The length of the diastema and of the premolar row is also closer to that of the 397 early Pliocene Simatherium from South Africa. We therefore propose a provisory attribution to 398 cf. Simatherium demissum as only horn cores material will permit a clear attribution. 


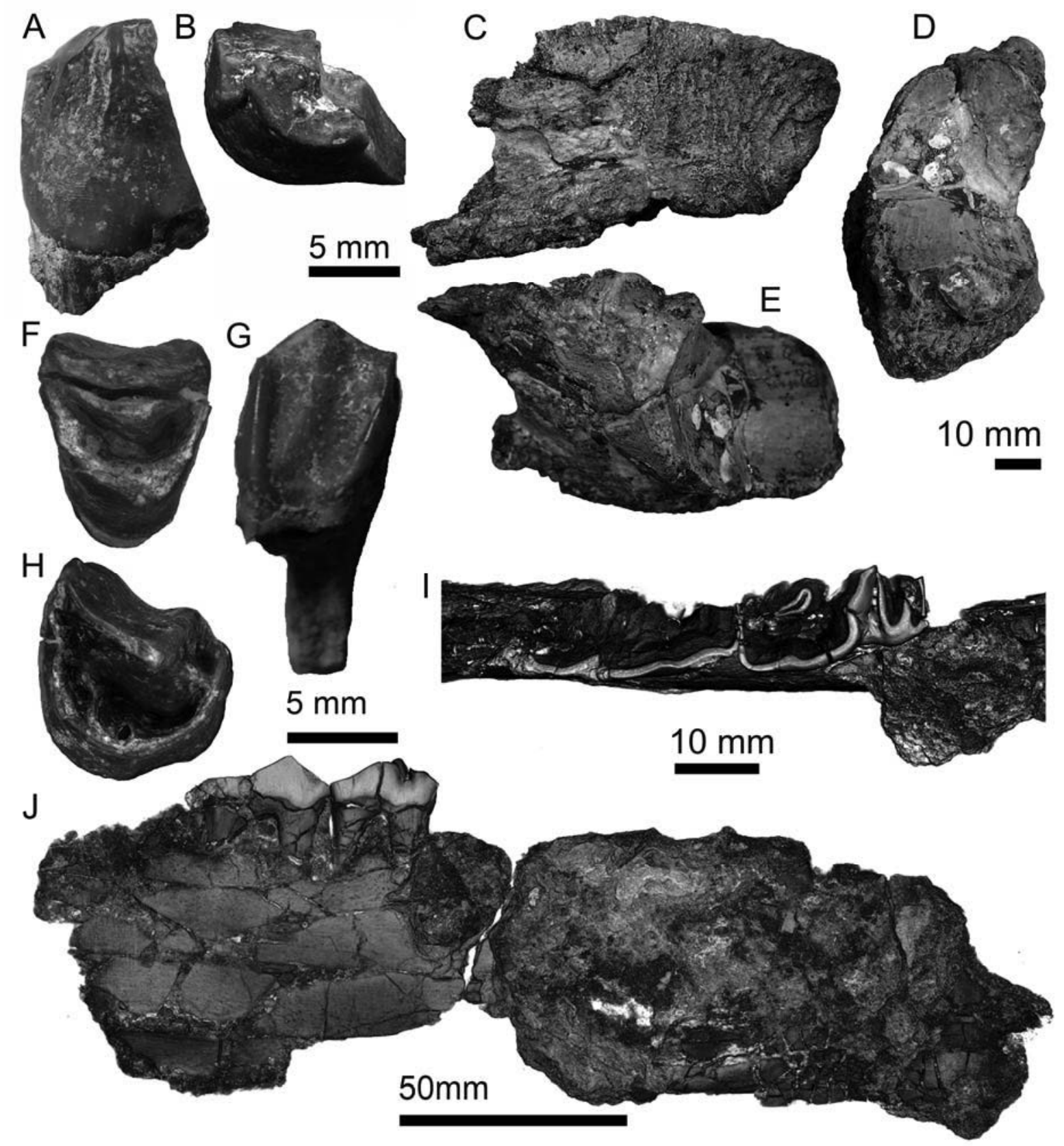

400

401 Fig. 3. [double column] Remains of Artiodactyla from Tobène. A-B: Disto-labial fragment of 402 left P4/ (SN-Tob-13-27) of Nyanzachoerus cf. jaegeri in labial (A) and occlusal (B) views. C403 E: a complete ungual phalanx of cf. Giraffa (SN-Tob-12-01) in plantar (C), proximal (D) and 404 dorsal (E) views. F-G: Upper right P4/ of a cf. Caprinae (SN-Tob-12-09) in occlusal (F) and 405 labial (G) views. H: Upper right P3/ (SN-Tob-15-19) of Antilopini indet. in occlusal view. I-J: 406 3D reconstruction of left mandible with fragmentary and worn P/4-M/1 of cf. Simatherium 407 demissum (SN-Tob-12-14) in occlusal (I) and lingual (K) views. 
3.6. Description of Antilopini indet.

410

411

Class Mammalia Linnaeus, 1758

412

Order Cetartiodactyla Montgelard, Douzery and Catzeflis, 1997

413 Suborder Ruminantia Scopoli, 1777

414 Subfamily Antilopinae Gray, 1821

415

416

Antilopini indet.

417

\subsubsection{Studied material}

419

420

Unworn upper right P3/ (SN-Tob-15-19; Fig. 3H).

421

422

\subsubsection{Description}

423

424

The P3/ is long with a paracone displaced mesially; the styles are marked but not prominent

425 and the mesial style is shallow and partly overhangs the labial wall to almost reach the paracone rib. A profound groove is visible between this style and the paracone rib. The latter is salient

427 and pinched. The mesial fossa is large and closed distally by a medial crista that joins the 428 postprotocrista to the postparacrista.

The tooth is quite small $(\mathrm{L}=9 \mathrm{~mm}$ and $\mathrm{W}=7.7 \mathrm{~mm}$ ) with slender cusps and a narrow 430 lingual margin. It belongs to one of the small-size bovid tribes (Antilopini, Caprini, Aepycerotini or Neotragini). Unfortunately, the dentition is not strongly relevant for a specific

432 attribution within these tribes (e.g., Geraads et al., 2012a). Compared with extant species and 
fossil taxa from Hadar (Geraads et al., 2012a), this tooth clearly differs from Aepycerotini premolars by a larger fossa, a marked labial rib, and less labially developed ribs; from Neotragini premolars by a larger fossa, less prominent mesial style, pinched labial rib of paracone and triangular occlusal shape instead of rectangular; and from Caprini by the presence of a large medial crista that joins the paracone and by being more mesio-distally elongated. It is similar in shape to the Antilopini premolar pattern apart from Litocranius, which displays brachyodont teeth. Its size matches with that of large gazelles such as the extant Nanger granti $(\mathrm{L}=9.3 \mathrm{~mm}$ and $\mathrm{W}=8.1 \mathrm{~mm})$, an Antilopini indet. from Hadar $(\mathrm{AL} \mathrm{132-3,} \mathrm{L}=8.2 \mathrm{~mm}$ and $\mathrm{W}=8$ $\mathrm{mm}$ ), and Gazella harmonae also from Hadar $(\mathrm{L}=8.5 \mathrm{~mm}$ and $\mathrm{W}=6.9 \mathrm{~mm}$; Geraads et al., 2012a). It is larger than the extant Eudorcas thomsonii $(\mathrm{L}=6.8 \mathrm{~mm}$ and $\mathrm{W}=6.6 \mathrm{~mm})$ and Gazella gazella $(\mathrm{L}=7.5 \mathrm{~mm}$ and $\mathrm{W}=6.5 \mathrm{~mm})$ and the fossil Gazella janenschi notably specimens from Laetoli, Tanzania (mean L=7.3 $\mathrm{mm}$ and mean $\mathrm{W}=7 \mathrm{~mm}$; Gentry, 2011).

Specific and even generic attribution to fossil Antilopini are difficult due to the scarcity of the material and to the fact that dentition is rarely described, figured or even published (Geraads et al., 2009; Haile-Selassie et al., 2009; Geraads et al., 2012a). Several antilopine taxa of similar size can occur in a same formation and only horn cores are diagnostic (e.g., Geraads et al., 2012a). We thus conclude that the P3/ can be attributed to an indeterminate Antilopini genus most probably close to large gazelles such as Nanger spp.

\subsection{Description of Caprinae indet.}

Class Mammalia Linnaeus, 1758

Order Cetartiodactyla Montgelard, Douzery and Catzeflis, 1997

Suborder Ruminantia Scopoli, 1777

Subfamily Caprinae Gray, 1821 
459 Caprinae indet.

460

461

3.7.1. Studied material

462

463

Upper right P4/ (SN-Tob-12-09; Figs 3F-G)

464

465

\subsubsection{Description}

466

467

The P4/ is bicuspid with crescent cristae. It is wider than long and characterized by a mesially displaced protocone, a large symmetric fossa, weak styles, and slightly pinched paracone rib.

469 A small central fold is visible distally; it forms a small spur (Fig. 3F). The P4/ is small, with 470 slender cusps and narrow lingual margin. It could belong to a tribe of small Antilopinae 471 (Antilopini, Aepycerotini or Neotragini) or Caprinae. It differs from premolars of Aepycerotini 472 by a larger fossa, a marked but not prominent labial rib, less labially protruding styles and a 473 narrower lingual margin. It differs from Neotragini by its larger fossa, less prominent parastyle, 474 pinched paracone labial rib, and a triangular occlusal shape rather than rectangular. Dimensions $475(\mathrm{~L}=7.3 \mathrm{~mm}$ and $\mathrm{W}=8.5 \mathrm{~mm})$ are similar to specimens of extant Gazella dorcas, but with a

476

477 weaker style development, and similar to the holotype of Gazella harmonae from Hadar (AL444-16, unfigured palate; Geraads et al., 2012a). Differences with G. harmonae consist in a slightly larger fossa, the presence of a small central fold and a more slanted disto-lingual margin. It differs from Antilopini by its mesially displaced protocone, its triangular outline with a distolingual flat border and its fossa that is not only mesially distributed but also distally extended. 
The flat labial wall of the P4/ with developed styles and weak rib resembles that of 483 Caprinae (Fig. 3G). This specimen is however less hypsodont than extant Ovis or Capra, and

484

485

486

487

488

489

490

491

492

493

494

495

496

497

498

499

500

501

502

503

504

505

506

its lingual border is not vertical but slanted with the lingual root inclined. On the lingual border, a small enamel bulge is visible at the level of the cervix. The labial face has two style ribs that diverge toward the crown apex (Fig. 3G) whereas these ribs are parallel in extant Caprini.

The Tobène specimen differs from the described P4/ of African fossil Caprinae (Bibi, 2011) such as Skouraia helicoides from the late Miocene of Morocco (Geraads et al., 2012). In most cases, only horn cores are discovered or described in African localities (Vrba, 1997; Bibi, 2011; Bibi et al., 2012), which prevents any precise attribution for the Tobène P4/. Caprinae is an Asian subfamily that dispersed repeatedly in Africa during the Pliocene (Gentry, 2010; Bibi, 2011; Bibi et al., 2012). Several authors (Bibi et al., 2012; Geraads et al., 2012b) have questioned the existence of putative endemic lineages of African caprines. This question is difficult to address due to the fragmentary nature of the Tobène material. In occlusal view, the Senegalese specimen resembles Capra dalii from Dmanisi (Bukhsianidze and Vekua, 2006) but it is less hypsodont. In this regard, it is quite similar to the P4/ of the type specimen of Capra primaeva from the Late Pliocene locality of Aïn Brimba, Tunisia (Arambourg, 1979). Indeed, this semi-hypsodont Caprini, sometimes attributed to another genus, Pseudocapra primaeva (Crégut-Bonnoure and Fernandez, 2018), also exhibits narrow styles on upper teeth, an angular protocone in occlusal view, and a labio-lingual enlargement that confers a concave profil to the lingual face. The Tunisian specimen is however larger $(\mathrm{L}=10 \mathrm{~mm}$ and $\mathrm{W}=12 \mathrm{~mm}$; Arambourg, 1979) than the senagalese premolar. The difficulty to identify a specific taxon within this subfamily on the sole basis of an isolated tooth leads us to attribute it to an indeterminate Caprinae.

\subsection{Description of Lutrinae indet.}


508

509

510

511

512

513

514

515

516

517

518

519

520

521

522

523

524

525

526

527

528

529

530

531

\section{Class Mammalia Linnaeus, 1758}

Order Carnivora Bowdich, 1821

Family Mustellidae Fisher, 1817

Subfamily Lutrinae Bonaparte, 1838

Lutrinae indet.

\subsubsection{Studied material}

Incomplete right femur preserving a fragmentary portion of the proximal part of diaphysis as well as a distal extremity with condyles (SN-Tob-12-02; Fig. 4). Most of the distal epiphysis is broken and the patellar groove is shifted. All fragments were found in association.

\subsubsection{Description}

SN-Tob-12-02 is a femur of a juvenile specimen. Its early ontogenetic stage is assessed through a lack of the lesser trochanter (i.e., only the epiphyseal plate is visible, Fig. 4A) and the presence of a prominent epiphyseal line. The proximal epiphysis is lacking, presumably broken at the level of the femoral proximal epiphyseal plate. A thin portion of the most distal part of the trochanteric crest and the floor of the trochanteric fossa are visible (Fig. 4A). The diaphysis is preserved with the exception of its distal third (Fig. 4A-B). The distal articular surface is wellpreserved, but only a minor portion of the lateral condyle articular surface remains (Fig. 4C-E). The femur is robust, short, and wide (Fig. 4). The diaphyseal transverse cross-section is compressed cranio-caudally above the patellar facet (Fig. 4K) and thus differs from that of 
ungulates, which is squared in transverse cross-section. The cranial extension of the patellar groove and the condyle caudal development are reduced (Fig. 4F) when compared to ungulates. The overall proportions of the femur clearly depart from those observed in primates and most carnivorans, apart from some mustelids. The distal epiphysis is robust and short craniocaudally, as in mustelids (Lewis 2008). We estimated the length of the femur to a maximal value of $120 \mathrm{~mm}$ to calculate the Femoral Robustness Index (FRI), i.e the midshaft craniocaudal diameter of femur divided by the femur length following Samuels et al. (2013). With a value of 0.108 , its FRI falls within the range observed in semiaquatic carnivorans (mean value of 0.09 in Samuels et al. 2013). Based on the 3D reconstruction (Fig. 4C, E, G), we also calculated the Femoral Epicondylar Index (FEI, i.e the epicondylar breadth of the distal femur divided by the femur length in Samuels et al. 2013) with a minimal estimated value of 0.253 , which corresponds to the mean value for semi-aquatic carnivorans (0.256 in Samuels et al. 2013). Both indices significantly discriminate semi-aquatic carnivorans from other locomotor groups (Samuels et al. 2013). These proportions show a strong resemblance of SN-Tob-12-02 with Lutrinae.

On the proximal epiphysis, the trochanteric fossa does not reach the level of the lesser trochanter (Fig. 4A, C). The lesser trochanter, even if badly preserved, was likely large and caudally positioned. On the lateral border, the gluteal tuberosities are poorly imprinted with no gluteal tubercle. The shaft is highly platymeric with a distinctive blade-like lateral border (Fig 4C, J). This condition is known in Lutrinae, especially in Aonyx and Lontra. The shaft flares at a more proximal level (Fig. 4G-H) than in terrestrial Mustelidae and rather resembles the condition of Lutrinae.

The distal epiphysis shows a proximo-distally extended and well excavated patellar groove (Fig. 4D-E, G), which is longer than in terrestrial mustelids. Its proximal end is located above the level of the proximal edge of the condyles. There is a marked sustrochlear hollow 
557

558

559

560

561

562

563

564

565

566

567

568

569

570

571

572

573

574

575

576

577

578

579

580

581

(Fig. 4G). In distal view (Fig. 4D-E), the medial patellar lip is cranially projected. We observe a cranio-caudal condylar asymmetry in favour of the medial condyle as in all compared mustelids; it is especially pronounced in Lutrinae including extinct ones (e.g. Lewis 2008; Peigné et al. 2008). The medial condyle of SN-tob-12-02 is characterized by a well imprinted and extensive pit on its medial surface for the medial collateral ligament (Fig4. F), a slight depression medially facing on the caudalo-proximal side for the medial part of $\mathrm{m}$. gastrocnemius, and a condyle that tapers distally (Fig. 4B-C).

The Tobène femur is characterized by an important development of the cortical bone. On longitudinal sections (Fig. 4H), we observed a peculiar thickening near the bone growth center. This distribution of the bone tissue is similar to that described in extant Lutrinae and differs from that of terrestrial mustelids (Houssaye and Botton-Divet 2018). The trabecular network has a larger extension in the diaphysis than in terrestrial mustelids (Fig. 4I, K) and resembles otter trabecular network (Houssaye and Botton-Divet 2018). This microanatomy pattern confirms an attribution of this specimen to the subfamily Lutrinae.

The overall dimensions of this femur are congruent with those of large extant otters, such as Enhydra and Pteronura (Lewis 2008). Its size is very close to that of the African Aonyx capensis, notably its length, FRI and FEI; it, however, displays larger mid-shaft diameter (Valenciano and Govender 2020). Lutrinae are represented by seven genera in the African fossil record and the systematics of this subfamily is essentially based on dental features (Werdelin and Peigné 2010). Specific or generic attributions of lutrine postcranial materials then entirely depend on associated dental material. Within the group of bunodont lutrine, Lewis (2008) showed that the morphology of the postcranial skeleton is more variable than the dental morphology. Some lutrine femurs have been described from African Mio-Pliocene deposits (Lewis 2008, Peigné et al. 2008, Geraads et al. 2011, Valenciano and Govender 2020). Most of them are larger than the Senegalese specimen, such as Sivaonyx from Langebaanweg and Toros- 
582 Menalla (Peigné et al. 2008, Valenciano and Govender 2020) and some bunodont lutrines from

583 Hadar, Omo, and West Turkana (Lewis, 2008). There is a tendency of size increase during the 584 Pliocene with the youngest specimens of the bunodont lineage being much larger (Geraads et 585 al. 2011). Only a fossil femur attributed to cf. Aonyx sp. from Toros Menalla (Peigné et al. 586 2008) is equivalent in size to Tob-2012-02. Unfortunately, the characters shared by the Chadian 587 specimen and Aonyx are not preserved in the Tobène femur. We then propose to assign SN588 Tob-12-02 to Lutrinae indet. 

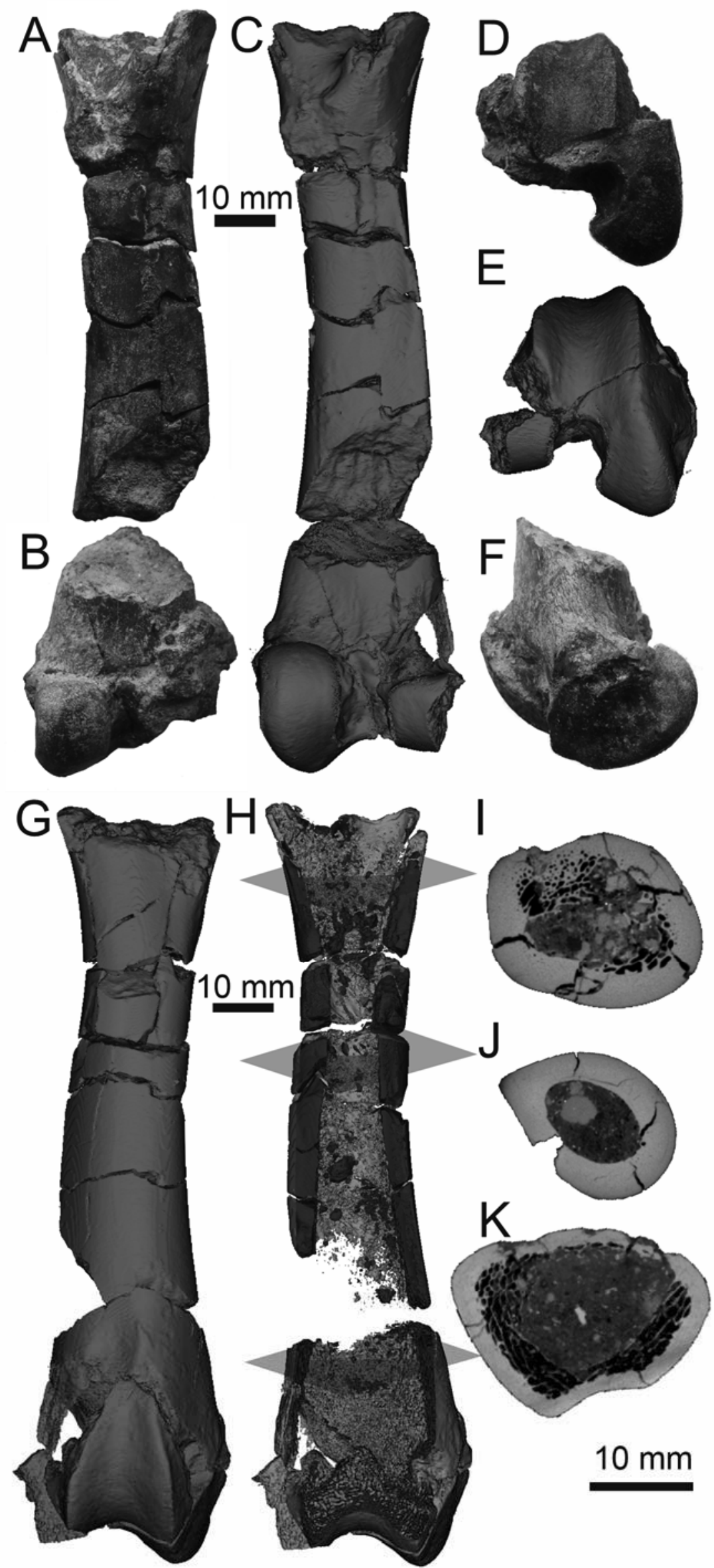
601

602

603

604

605

606

607

608

609

610

611

612

613

614

Fig. 4. [one and half column] Incomplete right femur of a Lutrinae indet. from Tobène (SNTob-12-02) and its 3D model reconstruction. Caudal (A and B), distal (D) and medial (F) views of the fossil; caudal (C), distal (E), cranial (G) views of the 3D model reconstruction. Coronal section along the proximo-distal axis of the shaft $(\mathrm{H})$ and transverse cross-sections set at proximal (I), midshaft (J) and distal (K) levels.

\subsection{Description of Mustelidae cf. Mellivorinae}

\section{Class Mammalia Linnaeus, 1758}

Order Carnivora Bowdich, 1821

Family Mustellidae Fisher, 1817

\section{Mustelidae cf. Mellivorinae}

\subsubsection{Studied material}

Proximal extremity of a right scapula (SN-Tob-15-18; Fig. 5D-F).

\subsubsection{Description}

The glenoid cavity is elliptical $(\mathrm{L}=13.6 \mathrm{~mm}$ and $\mathrm{W}=9.7 \mathrm{~mm})$, and roughly equivalent in size to that of the European otter. Its elliptical shape is unlike the rounded-one of ungulates (Fig. 5E). Moreover, the scapular neck is very short and robust, a feature also distinct from ungulates (Fig. $5 \mathrm{D}, \mathrm{F})$. The lateral border is continuous and not depressed above the spine, which recalls carnivorans such as Felis or Genetta. The coracoid process is not developed on the median 
portion of the supraglenoid tubercle and the cranial part of the glenoid cavity is not projected (Fig. 5D-F), which contrasts with the condition observed in primates as well as scansorial and arboreal carnivorans (Heinrich and Houde 2006).

In lateral view, the glenoid cavity is slightly concave, but less than in terrestrial primates (e.g., Theropithecus gelada) or some carnivorans (Genetta and Canis). The root of the spine is broken but was likely caudally inserted. The cranial border projects abruptly and directly after the neck, revealing a marked scapular notch (Fig. 5D, F), not as gradual as for primates and most of carnivorans. The caudal border is broken just below the spine insertion.

Despite its fragmentary nature, the morphology of the glenoid cavity remains similar to that of Mustelidae or Mephitidae such as Spilogale (Heinrich and Houde, 2006) and the dimensions are similar to large Mustelidae. It differs from Meles and Lutra by a weak development of the cranial lip of its glenoid cavity, a lack of coracoid process and a deeper scapular notch. Overall, SN-Tob-15-18 closely resembles the scapula of Mellivora, both taxa lacking the coracoid process and the protruding cranial lip of the glenoid cavity. Additionally, the rim of the glenoid cavity is extended in both taxa. The scapular notch of SN-Tob-15-18 is deep as in Mellivora capensis (Rose et al., 2014). The overall size of the Tobène specimen is nevertheless smaller than specimens of extant Mellivora (OM180 in NMK; not numbered specimens in CNRD). As the preservation state of SN-Tob-15-18 is inadequate for precise taxonomic attribution and given that no scapula of fossil Mellivora were described so far, we cautiously attribute this specimen to an indeterminate Mustelidae, probably close, or belonging to, Mellivorinae.

\subsection{Description cf. Genetta sp.}


Order Carnivora Bowdich, 1821

641

642

643

644

645

646

647

648

649

650

651

652

653

654

655

656

657

658

659

660

661

662

663

664

Family Viverridae Gray, 1821

Subfamily Genettinae Gray 1864

cf. Genetta sp.

\subsubsection{Studied material}

\subsubsection{Description} carnivoran.

Distal epiphysis of a right humerus (SN-Tob-12-08, Fig. 5A-C).

The distal fragment displays a biepicondylar breadth of $11.8 \mathrm{~mm}$. It is broken near the olecranon fossa, and only the distal part of the supracondylar foramen is noticeable (Fig. 5A-B). The presence of this foramen supports our taxonomic attribution of SN-Tob-12-08 to a small

Felidae and Civettictis differ from this specimen by a salient and distally developed medial trochlear keel and by a relatively narrower articular surface. The specimen also differs from similar-sized Mustelidae by an angulate medial epicondyle (flat in Martes), an elliptical supracondylar foramen (rounded in Martes), a perforation of the olecranon fossa, and an incipient but noticeable zona conoidea (i.e, area between lateral lips of trochlea and capitulum).

The Tobène specimen does not resemble carnivoran arboreal walker and climber (following the classes established in Taylor (1974)) due to the weak development of the medial epicondyle and the presence of a shallow zona conoidea (Fig. 5A-C). It also differs from terrestrial species such as Civettictis and Ichneumia and fossorial species such as Mungos that display a deep zona 
665

666

667

668

669

670

671

672

673

674

675

676

677

678

679

680

681

682

683

684

685

conoidea, which prevents supinatory movements (Taylor, 1974). In regard to substrate and positional behaviors, the specimen SN-Tob-12-08, is a quadruped, with probable mixed substrate preferences like Genetta. Viverridae and Herpestidae also present a perforation of the olecranon fossa. Even if uncommon in the sample studied by Taylor (1974), all the specimens of Genetta genetta $(\mathrm{n}=10)$ observed for the present study display this perforation. In SN-Tob12-08, the medial lip of the trochlea is straight in cranial view (Fig. 5A), whereas it is slanted in the observed Herpestidae (Herpestes edwardsi (UM), H. ichneumon and Ichneumia albicauda (in Taylor, 1974). The capitulum is larger and less separated from the lateral border of the articulation than in Herpestidae but is similar to Genetta genetta. In Herpestes, the supracondylar foramen is distally-set and occupies a median position in regard to the axis defined by the medial trochlear keel. In the Tobène specimen, the foramen is separated from the trochlear keel and positioned on the same proximo-distal axis as in Genetta genetta. Moreover, the trochlea in Herpestes is more cranially projected than the capitulum in distal view, unlike in Genetta and the Tobène specimen that both show equivalent cranial projections (Fig. 5C).

The Tobène specimen resembles most Genetta genetta and displays only slight differences with this species including a smaller size $(\mathrm{W}=13.1 \mathrm{~mm}$ for Genetta genetta versus $\mathrm{W}=11.8 \mathrm{~mm}$ for SN-Tob-12-08) and a less cranio-caudally compressed medial epicondyle. Due to the fragmentary nature of SN-Tob-12-08 and the lack of a large humeral comparative fossil sample (especially with other small viverrids), we propose a taxonomic attribution to cf.

\section{Genetta.}




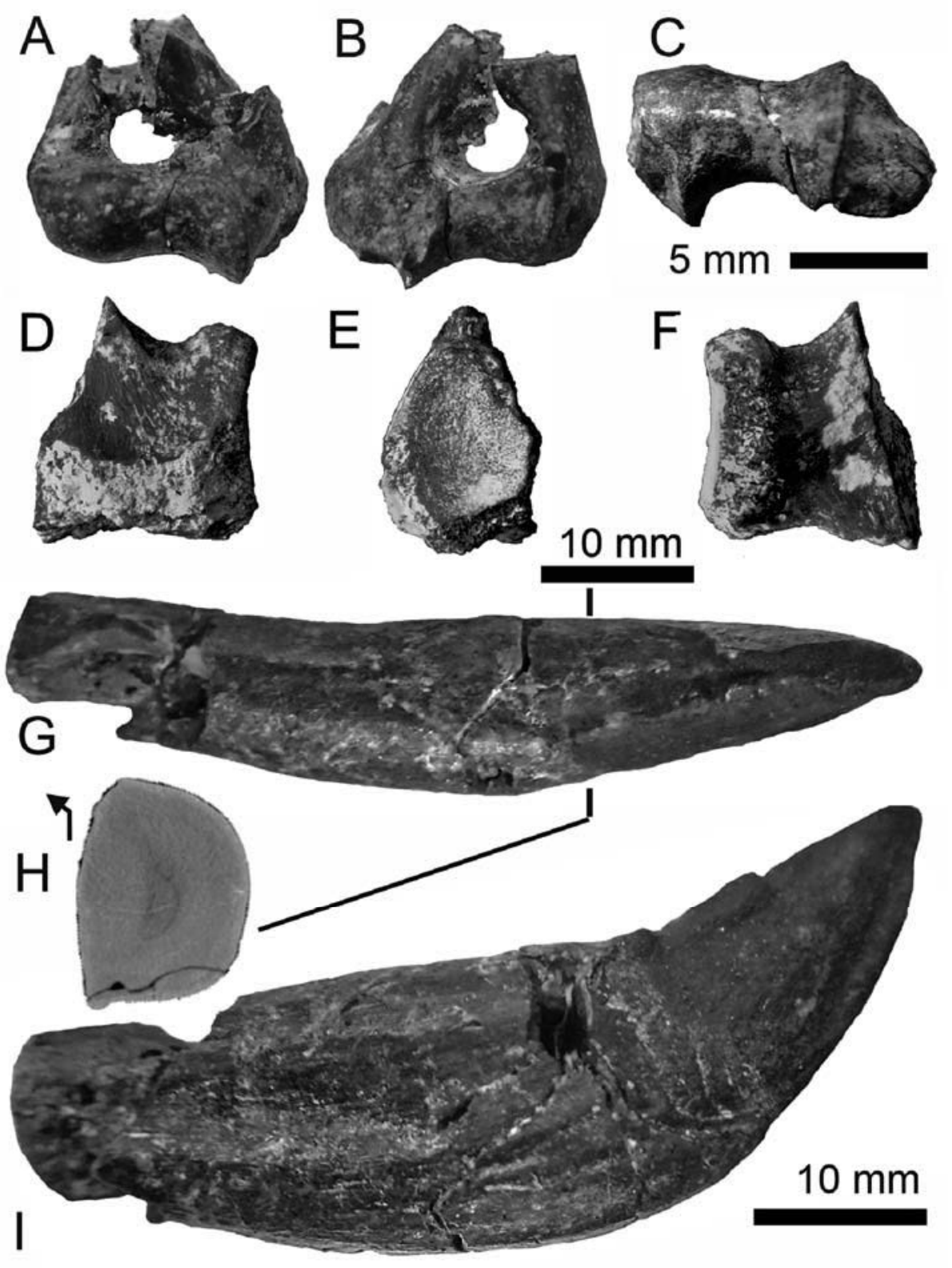

686

687 Fig. 5. [one and half column] Remains of Carnivora from Tobène. A-C: Distal epiphysis of a 688 right humerus of cf. Genetta sp. (SN-Tob-12-08) in cranial (A), caudal (B) and distal (C) views. 689 D-F: Proximal extremity of a right scapula of a Mustelidae cf. Mellivorinae (SN-Tob-15-18) in 690 lateral (D), proximal (E) and medial (F) views. G-I: Left lower canine of Homotherium sp. (SN691 Tob-12-06) in distal (G) and lingual (I) views, with a cross section at cervix (H). The arrow 692 indicates the mesio-lingual direction. 
695

696

Class Mammalia Linnaeus, 1758

697

Order Carnivora Bowdich, 1821

698 Family Felidae Fisher, 1817

699 Subfamily Machairodontinae Gill, 1872

700

Tribe Homotherini Fabrini, 1890

701

Genus Homotherium Fabrini, 1890

702

703

Homotherium sp.

704

705

\subsubsection{Studied material}

706

707

Isolated complete left lower canine with important distal wear (SN-Tob-12-06; Fig. 5G-I).

708

709

\subsubsection{Description}

710

711

The lower canine is a fang with mesial and distal keels, an enlarged root and, a continuous

712 curvature along the crown-root length (Fig. 5I). This tooth belongs to a large carnivoran with

713 small lower canines, similar in size (comparing sections at cervix) to Panthera pardus but one-

714 third smaller in crown height. Indeed, the crown of SN-Tob-12-06 is $24.3 \mathrm{~mm}$ in height and the 715 root is $37.7 \mathrm{~mm}$ in length. The measured crown linguolabial length is $10.8 \mathrm{~mm}$ at cervix and 716 the crown mesiodistal length is $13.7 \mathrm{~mm}$. This small size compared to other carnivorans, 717 together with the compression of the crown associated with a crenulation of the distal keel 718 indicate that it belongs to a Felidae Machairodontinae (Christiansen, 2013). The lingual flank 
is flat and the labial flank is convex, which clearly differs from the more conical lower canine of Dinofelis (Werdelin and Lewis, 2001). The occlusal perimeter of the crown is D-shaped (Fig. 5H) and not oval as in Machairodus (Antón et al., 2004). It is also considerably smaller than all specimens of Machairodus aphanistus, notably regarding the crown height (Antón et al., 2004). A small distal wear facet is present (Fig. 5G). This implies that upper and lower canines occlude in opposition, a characteristic feature of Homotherium compared to Machairodus following de Beaumont (1975). Two keels are present, one mesio-lingual and one disto-lingual. The latter displays strong crenulation, which differs from that of Megantereon (Christiansen and Adolfssen, 2007). Even largely obliterated by wear, the mesial keel is finely serrated and occupies a lingual position contrary to late Miocene Homotherini such as Amphimachairodus giganteus, which displays a more mesially oriented keel (Morlo and Semenov, 2004). Moreover, the late Miocene machairodontines such as Amphimachairodus usually have a larger and less curved lower canine (Salesa et al., 2012). Unfortunately, the lower canine of Lokotunjailurus from Lothagam, Kenya, remains unknown (Werdelin, 2003). The association of a flattened, small, and curved lower canine with mesial and distal crenulations is consistent with the description of the genus Homotherium (Antón et al., 2014), and congruent with what is expected for a Plio-Pleistocene African Machairodontine (Sardella and Werdelin, 2007).

The lower canine fits within the size range of Homotherium crenatidens from the early Pleistocene of Kuruksay (Tajikistan) and Liventsovka (Russia) (Sotnikova and Titov, 2009) and in the variation range of $H$. latidens from Incarcal (Spain; Antón et al., 2014). Unfortunately, only one lower canine of Homotherium was published in the African fossil record (Geraads et al., 2015). Compared to this specimen of Homotherium hadarensis from Dikika (Ethiopia, 3.5-2.9 Ma according to Geraads et al., 2015), the Tobène specimen has a shorter root; it is also slenderer and shows a more pronounced curvature between crown and root in lateral view (Fig. 5F-G). In distal view, the crown is twisted labially with regard to the 
root as in $H$. hadarensis. In the latter species, the crown apex is twisted lingually unlike SNTob-12-06. A small distal crest is observable labially to the main keel but this is probably due to important enamel wear. The root is bilobed with lateral lingual and labial gutters at midshape, which are more important than those observed in $H$. hadarensis. Other species of the genus are known from Africa: H. problematicum and H. africanum (Antón et al., 2014) but no lower canine has been recovered and described for these species. It can be mentioned that $H$. africanum from Aïn Brimba, Tunisia, (Werdelin and Peigné, 2010) firstly attributed to Machairodus, differs from other Homotherium by its small size and the retention of some primitive features (Petter and Howell, 1987). An unpublished mandible of Homotherium from the locality ARA-VP-1 from the Aramis Member of the Sagantole Formation, Ethiopia (White, pers. comm. 2018) has canines similar in size to those of the Tobène specimen. These canines show comparable crown curvature in lingual view and no crown apex shift in distal view. Postcranial remains of Homotherium from Kanapoi are considered to be smaller than in other East African localities (Werdelin and Lewis, 2020), which is also congruent with the small canine of Tobène and Aramis and suggests the existence of a small species of Homotherium at least known from the early Pliocene of Africa.

Due to the scarcity of the fossil record and to the weak diagnostic support given by a lower canine, we can only conclude on the presence of the felid Homotherium sp. in Tobène.

\section{Discussion}

\subsection{Age of the fossiliferous conglomerate}

The age of the Tobène fossiliferous locality is first discussed from the perspective of paleoweathering chronology, then from the perspective of biochronology. 

erosion/weathering history of its landscape. During the Neogene, three main pediment systems

771

772 (erosion and transportation land surfaces) formed under a dominantly semi-arid climate (Chardon et al., 2018). Each of these surfaces was weathered/duricrusted under seasonally humid climate before a return to semi-arid climate that favored the development of the next pediment (Beauvais and Chardon, 2013). At the Tambao (Northern Burkina Faso) type Sahelian locality, Ar-Ar geochronology of K-Mn oxydes formed in the ferricrete/weathering profile of each pediment allowed bracketing the three Neogene periods of duricrusting under humid climate at ca. 18-11 Ma, 7-6 Ma, and 3 Ma (Beauvais et al., 2008; Fig. 6). More precisely, the youngest weathering episode is constrained between 3.4 Ma and 2.9 Ma (W3 period in Fig.6) and ascribed to the "Low glacis" i.e., the youngest and lowest pediment system in West Africa (Beauvais et al., 2008). As the last pre-Ogolian lateritic weathering episode of regional extent, this period may correspond to the formation of the ferricrete that developed on the fossiliferous conglomerate or to that formed on the overlying aeolian sand unit (Fig. 1). Given the duration of the last weathering period dated in Tambao, the two superimposed duricrusting episodes documented in Tobène may as well have been produced during the $0.5 \mathrm{Ma}$ time laps between 3.4 and 2.9 Ma. We therefore propose to correlate the weathered fossiliferous conglomerates and its overlying sandstones with the Low glacis landscape stage recorded over most West Africa (Chardon et al., 2018), before the W3 regional weathering episode (Fig. 6). Those interpretations would be consistent with the fact that, East of the Senegalo-Mauritanian basin, the Ogolian sands (i.e., the youngest formation in the quarry, Fig. 1) are the oldest deposits overlying the youngest of the three West African pediment systems (Michel, 1973). In conclusion, the Tobène fossiliferous locality is therefore proposed to have a minimum age of 3.4 Ma (Fig. 6). 


\begin{tabular}{lllll}
\hline Class & Order & Family & Subfamily/tribe & Genus/species \\
\hline Reptilia & Crocodylia & Crocodylidae & & cf. Osteolaemus \\
Mammalia & Proboscidea & Deinotheriidae & & Deinotherium bozasi \\
& Cetartiodactyla & Suidae & Tetraconodontinae & Nyanzachoerus cf. jaegeri \\
& & Giraffidae & Giraffinae & cf Giraffa \\
& Bovidae & Bovini & cf. Simatherium demissum \\
& & Antilopini & indeterminate \\
& & Caprinae & indeterminate \\
& Carnivora & Lustelidae & Lutrinae & indeterminate \\
& & cf. Mellivorinae & indet \\
& & Giverridae & Genettinae & cf. Genetta \\
& & Felidae & Machairodontinae & Homotherium sp. \\
\hline
\end{tabular}

Table 1. Faunal list of Tobène.

795

Most taxa from the Tobène locality date to late Miocene and were present in Africa during the Pliocene (Giraffa, Deinotherium bozasi, Osteolaemus, large lutrines and large gazelles; Tables 1 and 2). Small carnivorans (close to Mellivora and Genetta) are well represented in the Pliocene. The earliest occurrence of Mellivora is from Langebaanweg and other remains attributed to the genus, even if common in Pliocene localities of Northern Africa, Southern Africa and Eastern Africa (Geraads, 1997; Werdelin and Peigné, 2010), have arguable species determination (Werdelin and Peigné, 2010). These specimens were usually referred to the extant Mellivora capensis. Occurrence of Genetta spp. is common in the Late MiocenePleistocene of Africa. Following Werdelin and Peigné (2010), the earliest fossil remain of the genus that suffers no ambiguity of identification is from Kanapoi, Kenya (4-4.2 Ma).

Three specimens from Tobène seem to present affinities with typical forms of early Pliocene African localities considered to belong to the recently defined African Land Mammal 
Age (AFLMA) Kerian dated from 5.3 to 3.6 Ma (Fig. 6; Van Couvering and Delson, 2020). First, the Tobène suid specimen has a morphology that is more congruent with species of Nyanzachoerus known between 5.5 Ma and $3 \mathrm{Ma}$ than with any other African suids. Its tentative attribution to the species Nyanzachoerus jaegeri, with a wide geographic distribution in Africa from Tunisia (Coppens 1971a) to, possibly, South Africa (Cooke and Hendey 1992), suggests a more precise age closer to $4 \mathrm{Ma}$, this species being temporally bracketed between ca. $5 \mathrm{Ma}$ (e.g., Apak Member at Lothagam, Harris and Leakey 2003) and 3.66 Ma (Woranso-Mille, Reda et al. 2019, see Fig. 6). The canine of Homotherium is similar to that from ARA-VP-1, Aramis (4.4 Ma; White et al. 2009) and belongs to a small African Homotherium possibly also present in Kanapoi (Werdelin and Lewis, 2020). The origin of Homotherium is supposed to be nested within African Amphimachairodus from the late Miocene-earliest Pliocene (Werdelin and Sardella, 2006; Werdelin and Lewis, 2020). To date, the earliest known Homotherium are from Odessa catacombs (Ukraine, 4.2 Ma; Sotnikova and Titov, 2009), Lonyumun Mb, Koobi Fora (4.35-4.1 Ma), and Kanapoi (Kenya, 4.2 Ma; Werdelin and Lewis, 2020). The specimen from Langebaanweg is considered as an advanced Amphimachairodus (Werdelin and Sardella, 2006). The lower canine from Tobène could represent an unnamed early African form of Homotherium, which partially fills the gap with the Amphimachairodus lineage. This would therefore constrain the maximum age of Tobène at the first occurrence of Homotherium near 4.4 Ma (Aramis and Lonyumun Mb, Koobi Fora; Fig. 6). Finally, specimens that resemble the mandible of cf. Simatherium demissum from Tobène have been reported from Kanapoi (Harris et al. 2003), even if its species attribution remains uncertain (Geraads et al., 2013; Geraads and Bobe, 2017), and from Kuseralee members of the Sagantole Formation in the Middle Awash (Ethiopia; Haile-Selassie et al., 2009). The material from Tobène could be regarded as an early Pliocene Bovini. Geographically, the closest early Pliocene Bovini attributed to Simatherium sp. are from Kossom Bougoudi and Kollé, Chad (Brunet et al., 1998, 2000). Another 


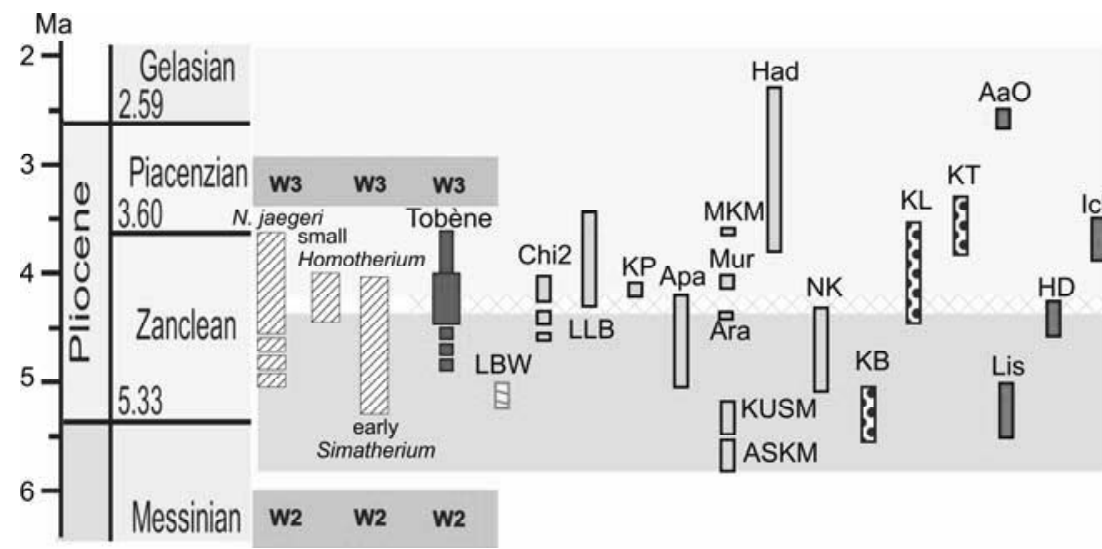
Ma as a minimum age for Tobène. (Fig. 6).

indeterminate Bovini is present in the early Pliocene of Lissasfa in Morocco (Geraads et al., 2010), but likely belongs to Ugandax. The systematic of early Bovini needs to be clarified and the mandibular remains from Tobène are too fragmentary to propose a clear specific or even generic attribution. Such early Bovini with large and low-crowned teeth have only been discovered in early Pliocene localities (“early Simatherium" Fig. 6, Table 2), which suggests 4

Our results indicate, all species identified in the Tobène conglomerate (Table 1) are younger than the beginning of the Pliocene (5.3 Ma) and older than 3.4 Ma i.e., onset of the last regional weathering episode in Sahel (Fig. 6; Beauvais et al., 2008). The comparison of the Tobène fauna with most African Late Neogene localities indicates an early Pliocene age for the Tobène fossiliferous conglomerate, which we tentatively propose were formed during the Kerian AFLMA most likely between 4.4 and $4 \mathrm{Ma}$, based on the three taxa discussed above

848 Fig. 6. [double column] Chronological distribution of the Tobène fauna compared to selected

849 Pliocene localities in Africa and chronological extension of some pertinent mammal remains found in Tobène. AB Aïn Brimba, Tunisia (Arambourg 1979); Apa: lower Apak member of the

851 Nachukui Formation, Lothagam, Kenya (McDougall and Feibel, 2003); Ara: Ara-VP-1, 852 Aramis, Middle Awash Ethiopia (White et al., 2009); ASKM and KUSM: Asa Koma Member 
853

854

855

856

857

858

859

860

861

862

863

864

865

866

867

868

869

870

871

872

873

874

875

876

877

of the Adu-Asa Formation and Kusarelee Member of the Sagantole Formation, Middle Awash,

Ethiopia (Haile-Selassie and WoldeGabriel, 2009); Chi2: Chiwondo Unit 2, Malawi (Bromage et al., 1995); Had: Hadar, Afar region, Ethiopia (Reed, 2008); HD: Hamada Damous, Tunisia (Coppens, 1971b); Ich: Garaet Ichkeul, Tunisia (Arambourg 1979); KB: Kossom-Bougoudi, Chad (Brunet et al., 2000; Lebatard et al., 2008); KL: Kolle, Chad (Brunet et al., 1998; Lebatard et al., 2008); KP: Kanapoi, Kenya (Harris et al. 2003); KT : Koro-Toro, Chad (Brunet et al., 1995); LBW: Langebaanweg, South Africa (Gentry, 1980; Roberts et al., 2011); Lis: Lissasfa, Morocco (Raynal et al., 1999); AaO: Ahl Al Oughlam, Morocco (Zouhri et al., 2017); LLB: Lower Laetolil Beds, Laetoli, Tanzania (Harrison, 2011a, 2011b); MKM: MKM-VP-1, Makah Mera, Woranso-Mille, Afar, Ethiopia (Haile-Selassie and Ryan, 2019); Mur: Mursi, Omo valley, Ethiopia (Drapeau et al., 2014); NK : NKondo Formation, Uganda (Simon et al., 2017). W2 and W3: weathering/duricrusting periods in Tambao, Burkina Faso, after Beauvais et al. (2008). Dark grey and light grey zones are the temporal distributions of the genus Ardipithecus and Australopithecus, respectively. Time scale is from Hilgen et al. (2012).

\subsection{Paleobiogeography and paleoenvironment}

Only few Neogene continental fossiliferous localities are known from western Africa. Most of them correspond to Pleistocene-Holocene deposits, notably from northern Mauritania (e.g. Zouérate and Chami; Coppens et al. 1972; Guérin 1980). A Nigerien locality (unknown precise location, Niger N885) has been dated from the late Miocene (Pickford et al. 2009). All these localities have yielded very few vertebrate remains and their age is clearly different from that proposed for the Tobène locality. At least 35 sub-contemporaneous (lower Pliocene) major fossiliferous localities (or formations) were described in Africa (Werdelin, 2010; see some of them in Fig. 6 and Table 2). Unfortunately, most of the northern African localities from this list 
are known only from micromammals (Benammi et al., 1996), which precludes comparison with the Tobène fauna. Lissasfa in Morocco (ca. 5.5 Ma) has yielded large mammals but is relatively poor in diversity (Raynal et al. 1999). Another Moroccan locality, Ahl Al Oughlam, is much more diverse but also more recent (about 2.5 Ma; Geraads et al., 2010). Some Pliocene localities in Tunisia have yielded large mammals such as the base of the Hamada Damous (Coppens, 1971b), the Garaet Ichkeul and Aïn Brimba (Arambourg, 1979). Those "Villlafranchian" localities have been dated close to 4.5 Ma, 3.7 Ma and 2.3 Ma, respectively (Van Couvering and Delson, 2020). However, Sahnouni et al. (2011) proposed an earlier age for Aïn Brimba, at ca. 2.8-3 Ma. Most Pliocene southern African localities consist of karst infillings (Pickford et al., 1994), and only the Langebaanweg locality (5.2-5 Ma; Roberts et al., 2011) can be relevantly compared to the Tobène fauna. Conversely, the East African Rift System is very rich for this time interval, notably i) in Ethiopia in the Omo valley (e.g., Mursi Fm.; Drapeau et al. 2014) and in the Afar Depression (Sagantole Fm, Hadar Fm. at Hadar, Dikika and WoransoMille; Haile Selassie and Woldegabriel, 2009, Reed, 2008, Geraads et al. 2015, Haile-Selassie and Ryan, 2019), ii) in Kenya, in the Turkana basin (e.g., Apak Member in Nachukui Fm., Kanapoi and Allia Bay; McDougall and Feibel, 2003, Harris et al. 2003) and in the Tugen Hills ( Mabaget and Chemeron Fm.; Gilbert et al., 2011), iii) in Tanzania (Lower Laetolil beds; Harrisson, 2011a,b), iv) in Malawi (Chiwondo Unit 2; Bromage et al., 1995), and v) in Uganda (Nkondo Fm.; Simon et al., 2017). Finally, Central Africa has yielded some important localities for this time period in Chad (Kossom Bougoudi, Kolle and Koro-Toro; Brunet et al., 1995, 1998, 2000).

This inventory shows that i) large mammalian faunas from the Neogene of Africa are best and mostly known from eastern Africa and that ii) western Africa remains a paleontological wasteland for Neogene continental faunas. Considering Pliocene times, western Africa is loosely bounded to the North by the locality of Lissasfa (Casablanca, Morocco at 2,400 km; 
904 Chad at 3,700 km; Brunet et al., 1998, 2000), i.e. the nearest known early Pliocene mammalian 905 faunas (Fig. 6).

906

\begin{tabular}{|c|c|c|c|c|c|c|c|c|c|c|c|c|c|c|}
\hline Tobène & LBW & Chi2 & LLB & KP & Mur & KUSM & Ara & MKM & NK & KL & KB & Lis & $\mathrm{AaO}$ & $\mathrm{AB}$ \\
\hline Osteolaemus & & & & & & & & & $\mathrm{X}$ & & & & & \\
\hline D. bozasi & & & & $\mathrm{X}$ & $\mathrm{X}$ & $\mathrm{X}$ & $\mathrm{X}$ & & & & & & & \\
\hline N. jaegeri & $\mathrm{X}$ & $\mathrm{X}$ & $\mathrm{X}$ & $\mathrm{X}$ & $\mathrm{X}$ & & $\mathrm{X}$ & $\mathrm{X}$ & $\mathrm{X}$ & $\mathrm{X}$ & & & & \\
\hline Giraffa & & & $\mathrm{X}$ & $\mathrm{X}$ & $\mathrm{X}$ & $\mathrm{X}$ & $\mathrm{X}$ & $\mathrm{X}$ & & $\mathrm{X}$ & $\mathrm{X}$ & & & $\mathrm{X}$ \\
\hline Early Bovini & $\mathrm{X}$ & $\mathrm{X}$ & & $\mathrm{X}$ & & $\mathrm{X}$ & $\mathrm{X}$ & & $\mathrm{X}$ & $\mathrm{X}$ & $\mathrm{X}$ & $\mathrm{X}$ & & \\
\hline (Simatherium) & & & & & & & & & & & & & & \\
\hline Large gazelle & & & $\mathrm{X}$ & & & & $\mathrm{X}$ & & & $\mathrm{X}$ & $\mathrm{X}$ & & $\mathrm{X}$ & $\mathrm{X}$ \\
\hline Caprinae & $\mathrm{X}$ & & & & & $\mathrm{X}$ & & & & & & & & $\mathrm{X}$ \\
\hline Lutrinae & $\mathrm{X}$ & & $\mathrm{X}$ & $\mathrm{X}$ & & $\mathrm{X}$ & $\mathrm{X}$ & $\mathrm{X}$ & $\mathrm{X}$ & & $\mathrm{X}$ & & $\mathrm{X}$ & \\
\hline Mellivorinae & $\mathrm{X}$ & & & & & $\mathrm{X}$ & & & & & & & X & \\
\hline Genetta & & & & $\mathrm{X}$ & & $\mathrm{X}$ & & & & & & & $\mathrm{X}$ & \\
\hline Homotherium & & & & $\mathrm{X}$ & & & $\mathrm{X}$ & $\mathrm{X}$ & & & & & & $\mathrm{X}$ \\
\hline (small) & & & & & & & & & & & & & & \\
\hline
\end{tabular}

908 Table 2. Geographic distribution of the taxon retrieved in Tobène in regard to African Pliocene 909 localities discussed in the text. AaO: Ahl Al Oughlam, Morocco (Zouhri et al., 2017); AB: Aïn 910 Brimba, Tunisia (Arambourg, 1979); Ara: Ara-VP-1, Aramis, Middle Awash Ethiopia (White 911 et al., 2009); Chi 2: Chiwondo Unit 2, Malawi (Bromage et al., 1995); KB: Kossom-Bougoudi, 912 Chad (Brunet et al., 2000; Lebatard et al., 2008); KL: Kolle, Chad (Brunet et al., 1998; Lebatard 913 et al., 2008); KP: Kanapoi, Kenya (Harris et al., 2003); KUSM: Kuseralee Mb. of Sagantole 914 Fm., Middle Awash, Ethiopia (Haile-Selassie and WoldeGabriel, 2009, Bibi, 2011); LBW: 915 Langebaanweg, South Africa (Gentry, 1980; Roberts et al., 2011; Valenciano and Govender 
2020); Lis: Lissasfa, Morocco (Raynal et al. 1999); LLB: Lower Laetolil Beds, Laetoli, Tanzania (Harrison, 2011a, 2011b); MKM: MKM-VP-1, Makah Mera, Woranso-Mille, Afar, Ethiopia (Haile-Selassie and Ryan, 2019); Mur: Mursi, Omo valley, Ethiopia (Drapeau et al., 2014); NK : NKondo Fm., Uganda (Simon et al., 2017).

An important result here is an apparent lack of endemism in the Senegalese fauna, at least at generic level. However, this interpretation could be biased by the fragmentary nature of the material preserved in Tobène. Some genera present in the Tobène fauna have a pan-African distribution as early as the early Pliocene: Mellivora, Genetta, Homotherium, and Giraffa were present in each of the main fossiliferous regions (Table 2). It is noteworthy that remains confidently attributed to Giraffa in Northwestern Africa are only known from Aïn Brimba at the end of the Pliocene (Arambourg, 1979). The species Deinotherium bozasi is also present in a large corridor extending from Malawi to Egypt (Sanders et al., 2010). It can now be considered as more widespread given the Tobène occurrence. Its absence from the Pliocene of Northwestern and Central Africa (Chad) could be linked to either relatively drier conditions or to sampling bias, Deinotherium being usually rare in fossil communities (except in Omo at Mursi, see Drapeau et al., 2014). However, such absence from localities that yielded numerous proboscidean remains (e.g., Garaet Ichkeul, Aïn Brimba, Koro-Toro) could also be explained by different ecological conditions in the Upper Pliocene of Morrocco, as previously proposed by Geraads (2010) based on the absence of both Deinotherium and Giraffa. In constrast, the presence of Deinotherium bozasi in Tobène could suggest biogeographical or environmental affinities with Pliocene East African localities. Whether or not the presence of Nyanzachoerus jaegeri in Tobène is confirmed, the wide distribution of this species (Reda et al. 2019) is already compelling. Indeed, it was already identified in northern (Tunisia), central (Chad), southern (South Africa), and eastern parts of Africa (Malawi, Tanzania, Kenya, and Ethiopia). For 
bovids, the comparisons established between the Tobène material and Simatherium demissum could imply relation with western and southern Africa. Nevertheless, Bovini (and Antilopini) are usually very diverse in most Pliocene African faunal lists, and the fragmentary condition of the Tobène remains precludes further speculation on ancient geographical distributions. Finally, if confirmed, the possible presence of a caprine could be interesting considering the relative proximity with the Atlas Mountain and southern Europe, even if this bovid group has a complex biogeographical history and is also known from eastern and southern Africa (Bibi, 2011). the limited size of the sample, the uncertain strict isochrony of the specimens, and the colluvial amalgamation of the fossils. Nevertheless, some first-order information may be retrieved. First, carnivorans are well represented and constitute one third of the collected fossils, whereas they are generally less abundant in fossil mammalian communities (e. g., 11\% in TM266 (Lefur et al. 2009); near 5\% in Aramis (White et al. 2009)). This could indicate taphonomical bias or simply a need to intensify field exploration in this area. The new Senegalese fauna does not seem to characterize a rainforest environment. Indeed, Homotherium is considered to have inhabited open environments and to have been more cursorial than other machairodontine felids (Werdelin and Lewis, 2020). Nyanzachoerus jaegeri is considered to have been a grazer and could be characteristic of savannah environments (Cerling et al., 2015; Manthi et al., 2017). as a closed-habitat species and its abundance in Mursi leads to suggest a mesic refugium in the

961 Omo valley (Drapeau et al., 2014). Thus, the Tobène Pliocene fauna suggests a woodland 962 environment but is not yet sufficiently documented to deciphere a paleoenvironmental picture. 963 At first sight, the Tobène fauna differs from that of the pene-contemporaneous Ethiopian locality of Aramis, which is rich in colobines and tragelaphines suggestive of a woodland habitat (White et al., 2009). It also differs from the possibly more open habitat described in 
Kollé, Chad (3.96 \pm 0.48 Ma; Lebatard et al., 2008), which is supported by the presence of rhinocerotids, equids, sivatheres and Kobus (Brunet et al., 1998) and by evidence for increasing aridity in Northern chad at this time (Zazzo et al., 2000; Novello et al., 2017). None of those characteristic mammals have been discovered in Tobène, which might simply be due to the small size of the Senegalese sample. Some differences in the faunal composition between eastern and northern/central African localities (notably for Deinotherium and Giraffa) were proposed to be linked to more arid conditions in northern/central Africa than in eastern Africa at least during the Late Pliocene (Geraads, 2010). Considering this hypothesis as well as the presence of both Deinotherium and Giraffa in Tobène, western Africa might display environmental conditions closer to that reconstructed in eastern Africa.

So far, Tobène shows more faunal similarities with Kanapoi, Aramis, and Kusarelee Members than with any other studied Pliocene localities (Table 2). Further documentation of the Tobène locality will be critical to validate those relations and reconstruct its paleoenvironment, which has proved pivotal in the discussions around the early evolution of australopithecines in eastern African localities (e.g. Manthi et al., 2020). Considering its temporal, spatial, and environmental assets, Tobène represents an important locality for potential discoveries of western African early hominins.

\section{Conclusions}

Most Sahelian sediments of putative late Cenozoic age are overlain by Quaternary sands that preclude surveys for fossil remains. In Senegal, Pliocene continental sediments are only exposed in mining quarries. The Tobène pit fauna shows that the latest iron duricrusts formed in West Africa in the late Pliocene may cap (and protect) continental strata that have the potential to fill a major gap in our understanding of African fossil faunas. Furthermore, the conspicuous and widespread occurrence of dated Neogene glacis landforms over West Africa 
991 and their systematic connections with alluvial terraces should open new perspectives for 992 African vertebrate paleontology.

994 evolution not only within a few specific areas (e.g. Eastern rift, Djurab desert) but at the scale 995 of the whole African continent. A large part of the African vertebrate history remains unknown, 996 notably during the Pliocene, which is a critical period of the hominins evolutionary history. 997 Western Africa might have played a major role in this history and the Tobène fauna described 998 here represents a first step in improving our evidence base in this region. The early Pliocene 999 age of this locality and some faunal similarities with localities from eastern Africa suggests 1000 there is a potential for further important discoveries at the Tobène site, notably regarding early 1001 hominid evolution. 
Acknowledgments: We would like to thank Mr El Hadji Mansour Sambe and Mr Ibrahima Gaye, authorities of the Industries Chimiques du Sénégal of the quarry of Taïba Ndiaye, for their logistic help and authorization. We also thank Faye Lassy of the ICS for his help in the field. The work benefited from the support of the Geology Department of the University Cheikh Anta Diop (Prof. E. Sow and Dr. Faaye Cisse S.). We are indebted to colleagues who allowed us accessing their collection: dir. Desalegn Abebaw, and T. Getachew from ARCCH in Addis Ababa; F. K. Manthi from the NMK in Nairobi; El-Hadj Mallah Baba, Nekoulnang Clarisse, and Adoum Mahamat from the CNRD, N'Djamena, Chad; D. Geraads for pictures of Homotherium from Dikika, and A. Houssaye for sharing information on lutrines. We warmly thank T. White and members of the Middle Awash Research Project for authorization to use the material of Middle Awash for comparisons and for sharing their identification of suids from these collections. We also acknowledge F. Guy, L. de Bonis, C. Blondel, M. Orliac, P. Gaubert for help in identification of specimens. Thanks to Suzanne Jiquel and Anne-Lise Charruault for preparation and to Sarah Jones for improving the English style of the manuscript. We express our gratitude to Daniel Sausson and the Waou staff at Mboro for their kind welcoming. 3D data acquisitions were performed using the $\mu$-CT facilities of the MRI platform member of the national infrastructure France-BioImaging supported by the French National Research Agency (ANR-10-INBS-04, «Investments for the future»), and of the Labex CEMEB (ANR-10-LABX0004) and NUMEV (ANR-10-LABX-0020).

Funding: This work was supported by the CNRS PICS Grant; the International Exchange Scheme of the Royal Society; the National Geographic Society's Global Exploration Fund (Northern Europe); the Sidney Sussex College (Cambridge, UK) and the IRD. 


\section{REFERENCES}

Antón, M., Salesa, M. J., Morales, J., Turner, A., 2004. First known complete skulls of the scimitar-toothed cat Machairodus aphanistus (Felidae, Carnivora) from the Spanish Late Miocene site of Batallones-1. J. Vert. Paleontol. 24, 957-969.

Antón, M., Salesa, M. J., Galobart, A., Tseng, Z. J., 2014. The Plio-Pleistocene scimitar-toothed felid genus Homotherium Fabrini, 1890 (Machairodontinae, Homotherini): diversity, palaeogeography and taxonomic implications. Quat. Sci. Rev. 96, 259-268.

Antunes, M. T., 1962. Presença de Osteolaemus tetraspis nas lagoas asfálticas de Sassa-Zau (Maiombe). In: Costa, J. (Ed), Estudos científicos oferecidos em homenagem ao Prof. Doutor J. Carríngton da Costa. Junta de Investigades do Ultramar, Lisbon, pp. 67-76.

Aoki, R., 1992. Fossil crocodilians from the late Tertiary strata in the Sinda Basin, eastern Zaire. Afr. Study Monogr. : Supplementary issue 17, 67-85.

Arambourg, C., 1979. Vertébrés villafranchiens d'Afrique du Nord. Fondation Singer-Polignac, Paris, $141 \mathrm{pp}$.

Basu, C., Falkingham, P. L., Hutchinson, J. R., 2016. The extinct, giant giraffid Sivatherium giganteum : skeletal reconstruction and body mass estimation. Biol. Lett. 12, e20150940.

Beaumont, G., de, 1975. Recherches sur les félidés (mammifères, carnivores) du Pliocène inférieur des sables à Dinotherium des environs d'Eppelsheim (Rheinhessen). Arch. Sci. Phys. Nat. Genève 28, 369-405.

Beauvais, A., Chardon, D., 2013. Modes, tempo, and spatial variability of Cenozoic cratonic denudation: the West African example. Geochem. Geophys. Geosyst. 14, 1590-1608. 
Beauvais, A., Ruffet, G., Hénocque, O., Colin, F., 2008. Chemical and physical erosion rhythms of the West African Cenozoic morphogenesis: the ${ }^{39} \mathrm{Ar}-{ }^{40} \mathrm{Ar}$ dating of supergene K-Mn oxides. J. Geophys. Res. 113, F04007.

Benammi, M., Calvo, M., Prévot, M., Jaeger, J.-J., 1996. Magnetostratigraphy and paleontology of Aït Kandoula basin (High Atlas, Morocco) and the African-European late Miocene terrestrial fauna exchanges. Earth Planet. Sc. Lett. 145, 15-29.

Bibi, F., 2011. Mio-Pliocene faunal exchanges and African biogeography: the record of fossil bovids. PLoS One 6, e16688.

Bibi, F., Vrba, E., Fack, F., 2012. A new African fossil caprin and a combined molecular and morphological bayesian phylogenetic analysis of Caprini (Mammalia: Bovidae). J. Evolution. Biol. 25, 1843-1854.

Brochu, C. A., 2020. Pliocene crocodiles from Kanapoi, Turkana Basin, Kenya. J. Hum. Evol. 140, 102410. DOI: 10.1016/j.jhevol.2017.10.003.

Bromage, T. G., Schrenk, F., Juwayeyi, Y.M., 1995. Paleobiogeography of the Malawi Rift: age and vertebrate paleontology of the Chiwondo Beds, northern Malawi. J. Hum. Evol. 28, $37-57$.

Brunet, M., Beauvillain, A., Coppens, Y., Heintz, E., Moutaye, A. H. E., Pilbeam, D., 1995. The first australopithecine 2500 kilometres west of the Rift Valley (Chad). Nature 378, 273274.

Brunet, M., Beauvilain, A., Geraads, D., Guy, F., Kasser, M., Mackaye, H.T., MacLatchy, L. M., Mouchelin, G., Sudre, J., Vignaud, P., 1998. Tchad: découverte d'une faune de mammifères du Pliocène inférieur. C. R. Acad. Sci. Paris 326, 153-158. 
1070

1071

1072

1073

1074

1075

1076

1077

1078

1079

1080

1081

1082

1083

1084

1085

1086

1087

1088

1089

1090

1091

Brunet, M., Beauvillain, A., Billiou, D., Bocherens, H., Boisserie, J.-R., Bonis, L. De, Branger, P., Brunet, A., Coppens, Y., Daams, R., Dejax, J., Denys, C., Duringer, P., Einsenman, V., Fanone, F., Fronty, P., Gayet, M., Geraads, D., Guy, F., Kasser, M., Koufos, G., Likius, A., Lopez-Martinez, N., Louchart, A., Maclatchy, L. M., Mackaye, H. T., Marandat, B., Mouchelin, G., Mourer-Chauvire, C., Otero, O., Peigné, S., Pelaez Campomanes, P., Pilbeam, D., Rage, J. C., De Ruitter, D., Schuster, M., Sudre, J., Tassy, P., Vignaud, P., Viriot, L., Zazzo, A., 2000. Chad : discovery of a vertebrate fauna close to the Mio-Pliocene boundary. J. Vert. Paleontol. 20, 205-209.

Bukhsianidze, M., Vekua, A., 2006. Capra dalii nov. sp. (Caprinae, Bovidae, Mammalia) at the limit of Plio-Pleistocene from Dmanisi (Georgia). Cour. Forsch. Senck. 256, 159-171.

Cerling, T. E., Andanje, S. A., Blumenthal, S. A., Brown, F. H., Chritz, K. L., Harris, J. M., Hart, J. A., Kirera, F. M., Kaleme, P., Leakey, L. N., Leakey, M. G., Levin, N. E., Manthi, F. K., Passey, B. H., Uno, K. T., 2015. Dietary changes of large herbivores in the Turkana Basin, Kenya from 4 to 1 Ma. Proc. Natl. Acad. Sci. USA 112, 11467-11472.

Chardon, D., Grimaud, J. L., Beauvais, A., Bamba, O., 2018. West African lateritic pediments: Landform-regolith evolution processes and mineral exploration pitfalls. Earth-Sci. Rev. 179, 124-146.

Christiansen, P., 2013. Phylogeny of the sabertoothed felids (Carnivora: Felidae: Machairodontinae). Cladistics 29, 543-559.

Christiansen, P., Adolfssen, J. S., 2007. Osteology and ecology of Megantereon cultridens (Mammalia; Felidae; Machairodontinae), a sabrecat from the late Pliocene-early Pleistocene of Senéze, France. Zool. J. Linn. Soc. London 151, 833-884. 
1092

1093

1094

1095

1096

1097

1098

1099

1100

1101

1102

1103

1104

1105

1106

1107

1108

1109

1110

1111

1112

Cooke, H. B. S., Hendey, Q. B., 1992. Nyanzachoerus (Mammalia: Suidae: Tetraconodontinae) from Langebaanweg, South Africa. Durban Mus. Nov. 17, 1-20.

Coppens, Y., 1971a. Une nouvelle espèce de suidé du Villafranchien de Tunisie, Nyanzachoerus jaegeri nov. sp. C. R. Acad. Sci. Paris 272, 3264-3267.

Coppens, Y., 1971b. Les vertébrés villafranchiens de Tunisie: gisements nouveaux, signification. C. R. Acad. Sci. Paris 273, 51-54.

Coppens, Y., Gouzes, R., Le Floch, R., Paquet, M. (1972). Découverte d'un gisement de vertébrés fossiles avec industrie acheuléenne près de Zouérate en Mauritanie. In, Hugot, J.-H. (Ed), 6e Congrès Panafricain de Préhistoire (Dakar, 1967). Imprimeries Réunies de Chambéry, Chambéry, pp. 457-461.

Crégut-Bonnoure, E., Fernandez, P. 2018. Perspectives morphométriques et phylogéniques du genre Capra au Pléistocène (Mammalia, Artiodactyla, Caprinae). Quaternaire 29(3), 243-254.

Delfino, M., 2008. New remains of Crocodylus checchiai Maccagno 1947 (Crocodylia, Crocodylidae) from the Late Miocene of As Sahabi, Libya. Garyounis Sci. Bull. 5, 111-118.

Drapeau, M. S. M., Bobe, R., Wynn, J. G., Campisano, C. J., Dumouchel, L., Geraads, D., 2014. The Omo Mursi Formation: a window into the East African Pliocene. J. Hum. Evol. 75, 64-79.

Eaton, M. J., 2010. Dwarf Crocodile Ostaeolaemus tetraspis. In: Manolis, S. C., Stevenson, C. (Eds.), Crocodiles. Status, Survey and Conservation Action Plan. Third Edition, Crocodile Specialist Group, Darwin, pp. 127-132.

Gentry, A. W., 1980. Fossil Bovidae (Mammalia) from Langebaanweg, South Africa. Ann. TransvaalMus. 79, 213-337. 
1113 Gentry, A. W., 2006. A new bovine (Bovidae, Artiodactyla) from the Hadar formation, 1114 Ethiopia. Trans. R. Soc. South Africa 61, 41-50.

1115 Gentry, A. W., 2010. Bovidae. In: Werdelin, L., Sanders, W. (Eds.), Cenozoic Mammals of 1116 Africa. University of California Press, Berkeley, pp. 741-796.

1117 Gentry, A. W., 2011. Bovidae. In Harrison T. (Ed.), Paleontology and Geology of Laetoli: 1118 Human Evolution in Context. Volume 2: Fossil Hominins and the Associated Fauna, Vertebrate 1119 Paleobiology and Paleoanthropology Series. Springer, Dordrecht, pp. 362-465.

1120 Geraads, D., 1997. Carnivores du Pliocène terminal de Ahl al Oughlam (Casablanca, Maroc). 1121 Geobios 30, 127-164.

1122 Geraads, D. 2010. Biogeographic relationships of Pliocene and Pleistocene North-western 1123 African mammals. Quatern. Int. 212(2), 159-168.

1124 Geraads, D., Bobe, R., 2017. Ruminants (Giraffidae and Bovidae) from Kanapoi. J. Hum. Evol. 1125 DOI: 10.1016/j.jhevol.2017.08.006

1126 Geraads, D., Thomas, H., 1994. Bovidés du plio-pléistocène d'Ouganda. Geology and 1127 Palaeontology of the Albertine Rift Valley, Uganda-Zaire. CIFEG, Publication Occasionnelle $112829,383-407$.

1129 Geraads, D., Melillo, S., Haile-Selassie, Y., 2009. Middle Pliocene Bovidae from hominid1130 bearing sites in the Woranso-Mille area, Afar region, Ethiopia. Palaeontol. Africana 44, 59-70.

1131 Geraads, D., Raynal, J.-P., Sbihi-Alaoui, F.-Z., 2010. Mammalian faunas from the Pliocene and 1132 Pleistocene of Casablanca (Morocco). Hist. Biol. 22, 275-285. 
1133 Geraads, D., Alemseged, Z., Bobe, R., \& Reed, D. (2011). Enhydriodon dikikae, sp. nov. 1134 (Carnivora: Mammalia), a gigantic otter from the Pliocene of Dikika, Lower Awash, Ethiopia. 1135 J. Vert. Paleontol. 31(2), 447-453.

1136

1137

1138

1139

1140

1141

1142

1143

1144

1145

1146

1147

1148

1149

1150

1151

1152

1153

1154

Geraads, D., Bobe, R., Reed, K., 2012a. Pliocene Bovidae (Mammalia) from the Hadar Formation of Hadar and Ledi-Geraru, Lower Awash, Ethiopia. J. Vert. Paleontol. 32, 180-197.

Geraads, D., El Boughabi, S., Zouhri, S., 2012b. A new caprin bovid (Mammalia) from the late Miocene of Morocco. Palaeontol. Africana 47, 19-24.

Geraads, D., Bobe, R., Manthi, F. K., 2013. New ruminants (Mammalia) from the Pliocene of Kanapoi, Kenya, and a revision of previous collections, with a note on the Suidae. J. Afr. Earth Sci. 85, 53-61.

Geraads, D., Alemseged, Z., Bobe, R., Reed, D., 2015. Pliocene Carnivora (Mammalia) from the Hadar Formation at Dikika, Lower Awash Valley, Ethiopia. J. Afr. Earth Sci. 107, 28-35.

Gilbert, C. C., Goble, E. D., Kingston, J. D., Hill, A., 2011. Partial skeleton of Theropithecus brumpti (Primates, Cercopithecidae) from the Chemeron Formation of the Tugen Hills, Kenya. J. Hum. Evol. 61, 347-362.

Guérin C., 1980. À propos des rhinocéros (Mammalia, Perissodactyla), néogènes et quaternaires d'Afrique : essai de synthèse sur les espèces et sur les gisements. In: Leakey, L., Ogot, B.A. (Eds), Proceedings of the $8^{\text {th }}$ Panafrican Congress of Prehistory and Quaternary Studies, september 1977. TILLMIAP, Nairobi, 58-63.

Haile-Selassie, Y., Ryan, T. M., 2019. Comparative description and taxonomy of new hominin juvenile mandibles from the Pliocene of Woranso-Mille (Central Afar, Ethiopia). J. Hum. Evol. $132,15-31$. 
1155

1156

1157

1158

1159

1160

1161

1162

1163

1164

1165

1166

1167

1168

1169

1170

1171

1172

1173

1174

1175

1176

Haile-Selassie, Y., WoldeGabriel, G., 2009. Ardipithecus kadabba: Late Miocene Evidence from the Middle Awash, Ethiopia. University of California Press, Berkeley, 641 pp.

Haile-Selassie, Y., Vrba, E. S., Bibi, F., 2009. Bovidae. In: Haile-Selassie, Y., Woldegabriel, G. (Eds.), Ardipithecus kadabba: late Miocene evidence from the Middle Awash, Ethiopia. University of California Press, Berkeley, pp. 277-330.

Harris, J. M. 2003. Bovidae from the Lothagam Succession. In: Leakey, M. G., Harris J. M. (Eds), Lothagam: the dawn of humanity in eastern Africa. Columbia University Press, New York, pp. 531-558.

Harris, J. M., Leakey, M. G., 2003. Lothagam Suidae. In: Leakey, M. G., Harris J. M. (Eds), Lothagam: the dawn of humanity in eastern Africa. Columbia University Press, New York, pp. 485-519.

Harris, J. M., Leakey, M. G., Cerling, T. E., Winkler, A. J. 2003. Early Pliocene tetrapod remains from Kanapoi, Lake Turkana Basin, Kenya. In: Harris, J. M., Leakey M. G. (Eds), Geology and vertebrate paleontology of the early Pliocene site of Kanapoi, northern Kenya. Contributions in Science, Natural History Museum of Los Angeles County 498. Allen Press, Lawrence, pp. 39-113.

Harris, J. M., Solounias, N., Geraads, D., 2010. Giraffoidea. In: Werdelin, L., Sanders, W. (Eds), Cenozoic Mammals of Africa. University of California Press, Berkeley, pp. 797-811.

Harrison, T., 2011a. Paleontology and geology of Laetoli vol. 1: Geology, Geochronology, Paleoecology and Paleoenvironment. Springer, Dordrecht, $401 \mathrm{pp}$.

Harrison, T., 2011b. Paleontology and geology of Laetoli vol. 2: Fossil Hominins and the Associated Fauna. Springer, Dordrecht, 600 pp. 
Hautier, L., Sarr, R., Tabuce, R., Lihoreau, F., Adnet, S., Domning, D. P., Samb, M., Hameh, P. M., 2012. First prorastomid sirenian from Senegal (Western Africa) and the Old World origin of sea cows. J. Vert. Paleontol. 32, 1218-1222.

Hautier, L., Sarr, R., Lihoreau, F., Tabuce, R., Hameh, P. M., 2014. First record of the family Protocetidae in the Lutetian of Senegal (West Africa). Palaeovertebrata 38, 1-7.

Heinrich, R. E., Houde, P. 2006. Postcranial anatomy of Viverravus (Mammalia, Carnivora) and implications for substrate use in basal Carnivora. J. Vert. Paleontol. 26(2), 422-435.

Hilgen, F.J., Lourens, L.J., Van Dam, J.A., 2012. The Neogene period. In: Gradstein, F.M., Ogg, J.G., Schmitz, M., Ogg, G., (Eds.), The Geologic Time Scale 2012. Elsevier, Amsterdam, pp. 923-978.

Houssaye, A., Botton-Divet, L. 2018. From land to water: evolutionary changes in long bone microanatomy of otters (Mammalia: Mustelidae). Biol. J. Linn. Soc. London 125(2), 240-249.

Joordens, J. C. A., Feibel, C. S., Vonhof, H. B., Schulp, A. S., Kroon, D., 2019. Relevance of the eastern African coastal forest for early hominin biogeography. J. Hum. Evol. 131, 176-202.

Kostopoulos, D. S., Sen, S., 2016. Suidae, Tragulidae, Giraffidae, and Bovidae. Geodiversitas 38(2), 273-298.

Lebatard, A.-E., Bourlès, D. L., Duringer, P., Jolivet, M., Braucher, R., Carcaillet, J., Schuster, M., Arnaud, N., Monié, P., Lihoreau, F., Likius, A., Mackaye, H. T., Vignaud, P., Brunet, M., 2008. Cosmogenic nuclide dating of Sahelanthropus tchadensis and Australopithecus bahrelghazali: Mio-Pliocene hominids from Chad. Proc. Natl. Acad. Sci. USA 105, 32263231. 
Lebrun, R., 2018. MorphoDig, an open-source 3D freeware dedicated to biology. Abstract book IPC5, Paris, France.

Lefur, S., Fara, E., Mackaye, H. T., Vignaud, P. Brunet, M. 2009. The mammal assemblage of the hominid site TM266 (Late Miocene, Chad Basin): ecological structure and paleoenvironmental implications. Naturwissenschaften 96 (5), 565-574.

Lewis, M. E. 2008. The femur of extinct bunodont otters in Africa (Carnivora, Mustelidae, Lutrinae). C. R. Palevol 7(8), 607-627.

Lihoreau, F., Sarr, R., Chardon, D., Boisserie, J.-R., Lebrun, R., Adnet, S., Martin, J.E., Sambou, B., Tabuce, R., Thiam, M., Hautier, L., in press. 3D model of a lutrine femur from Tobène, Senegal, related to the article" A fossil terrestrial fauna from Tobène (Senegal) provides a unique early Pliocene window in western Africa". MorphoMuseum. https://doi.org/10.18563/journal.m3.102

Manthi, F. K., Cerling, T. E., Chritz, K. L., Blumenthal, S. A., 2020. Diets of mammalian fossil fauna from Kanapoi, northwestern Kenya. J. Hum. Evol. 140, 102338. DOI: 10.1016/j.jhevol.2017.05.005

McDougall, I., Feibel, C.S., 2003. Numerical age control for the Miocene-Pliocene succession at Lothagam, a hominoid-bearing sequence in the Northern Kenya Rift. In: Leakey, M. G., Harris J. M. (Eds), Lothagam: the dawn of humanity in eastern Africa. Columbia University Press, New York, pp. 43-64.

Michel, P., 1973. Les bassins des fleuves Sénégal et Gambie, étude géomorphologique. Mémoire ORSTOM 63, 1-752. 
Mulitza, S., Prange, M., Stuut, J.-B., Zabel, M., von Dobeneck, T., Itambi, A. C., Nizou, J., Schulz, M., Wefer, G., 2008. Sahel megadroughts triggered by glacial slowdowns of Atlantic meridional overturning. Paleoceanography 23 (4), PA4206, DOI:10.1029/2008PA001637.

Morlo, M., Semenov, Y., 2004. New dental remains of Machairodus Kaup 1833 (Felidae, Carnivora, Mammalia) from the Turolian of Ukraine: significance for the evolution of the genus. Kaupia 13, 123-138.

Novello, A., Barboni, D., Sylvestre, F., Lebatard, A.-E., Paillès, C., Bourlès, D. L., Likius, A., Mackaye, H. T., Vignaud, P., Brunet, M., 2017. Phytoliths indicate significant arboreal cover at Sahelanthropus type locality TM266 in northern Chad and a decrease in later sites. J. Hum. Evol. 106, 66-83.

Pascal, M., Sustrac, G., 1989. Phosphorite deposits of Senegal. In: Notholt, A. J. G., Sheldon, R. P., Davidson, D. F. (Eds), Phosphate Deposits of the World: Volume 2, Phosphate Rock Resources. Cambridge University Press, Cambridge, pp. 233-246.

Peigné, S., Bonis, L. de, Likius, A., Mackaye, H. T., Vignaud, P., Brunet, M., 2008. Late Miocene Carnivora from Chad: Lutrinae (Mustelidae). Zool. J. Linn. Soc. 152(4), 793-846.

Petter, G., Howell, F.C., 1987. Machairodus africanus Arambourg, 1970 (Carnivora, Mammalia) du Villafranchien d'Aïn Brimba, Tunisie. Bull. Mus. Natl. Hist. Nat., Paris 9, 97119.

Pickford, M., 1994. Late Cenozoic crocodiles (Reptilia: Crocodylidae) from the Western Rift, Uganda. In Senut, B., Pickford, M. (Eds.), Geology and Palaeobiology of the Albertine Rift Valley, Uganda-Zaire, Vol. II - Palaeobiology CIFEG Occasional Publications, Orléans, pp. 137-155. 
1241

1242

1243

1244

1245

1246

1247

1248

1249

1250

1251

1252

1253

1254

1255

1256

1257

1258

1259

1260

1261

Pickford, M., Mein, P., Senut, B., 1994. Fossiliferous Neogene karst fillings in Angola, Botswana and Namibia. S. Afr. J. Sci. 90, 227-230.

Pickford, M., Coppens, Y., Senut, B., Morales, J., Braga, J., 2009. Late Miocene hominoid from Niger. C. R. Palevol 8(4), 413-425.

Prasad, G. V., de Broin, F. D. L., 2002. Late Cretaceous crocodile remains from Naskal (India): comparisons and biogeographic affinities. Ann. Paleontol. 88 (1), 19-71.

Raynal, J.-P., Lefevre D., Geraads, D., El Graoui, M. 1999. Contribution du site paléontologique de Lissasfa (Casablanca, Maroc) à une nouvelle interprétation du Mio-Pliocène de la Meseta. C. R. Acad. Sci., Paris 329, 617-622.

Reda, H. G., Lazagabaster, I. A., Haile-Selassie, Y., 2019 Newly discovered crania of Nyanzachoerus jaegeri (Tetraconodontinae, Suidae, Mammalia) from the Woranso-Mille (Ethiopia) and reappraisal of its generic status. J. Mamm. Evol. 26, 179-199.

Reed, K. E., 2008. Paleoecological patterns at the Hadar hominin site, Afar Regional State, Ethiopia. J. Hum. Evol. 54, 743-768.

Ríos, M., Sánchez, I. M., Morales, J., 2016. Comparative anatomy, phylogeny, and systematics of the Miocene giraffid Decennatherium pachecoi Crusafont, 1952 (Mammalia, Ruminantia, Pecora): State of the art. J. Vert. Paleontol. 36, e1187624.

Roberts, D. L., Matthews, T., Herries, A. I. R., Boulter, C., Scott, L., Dondo, C., Mtembi, P., Browning, C., Smith, R. M. H., Haarhoff, P., Bateman, M. D., 2011. Regional and global context of the Late Cenozoic Langebaanweg (LBW) palaeontological site: West Coast of South Africa. Earth-Sci. Rev. 106, 191-214. 
Rose, J., Moore, A., Russell, A., Butcher, M., 2014. Functional osteology of the forelimb digging apparatus of badgers. J. Mammal. 95, 543-558.

\section{Sahnouni, M., Van der Made, J., Everett, M., 2011. Ecological background to Plio-Pleistocene} hominin occupation in North Africa: the vertebrate faunas from Ain Boucherit, Ain Hanech and El-Kherba, and paleosol stable-carbon-isotope studies from El-Kherba, Algeria. Quat. Sci. Rev. 30(11-12), 1303-1317.

Salesa, M. J., Pesquero, M. D., Siliceo, G., Antón, M., Alcalá, L., Morales, J., 2012. A rich community of Felidae (Mammalia, Carnivora) from the late Miocene (Turolian, MN 13) site of Las Casiones (Villalba Baja, Teruel, Spain). J. Vert. Paleontol. 32, 658-676.

Samuels, J. X., Meachen, J. A., Sakai, S. A., 2013. Postcranial morphology and the locomotor habits of living and extinct carnivorans. J. morphol. 274(2), 121-146.

Sanders, W. J., Gheerbrant, E., Harris, J. M., Saegusa, H., Delmer, C., 2010. Proboscidea. In: Werdelin, L., Sanders, W. (Eds), Cenozoic Mammals of Africa. University of California Press, Berkeley, pp. 161-251.

Sardella, R., Werdelin, L., 2007. Amphimachairodus (Felidae, Mammalia) from Sahabi (latest Miocene-earliest Pliocene, Libya), with a review of African Machairodontinae. Riv. Ital. Paleontol. S. 113, 67-77.

Simon, B., Guillocheau, F., Robin, C., Dauteuil, O., Nalpas, T., Pickford, M., Senut, B., Lays, P., Bourges, P., Bez, M., 2017. Deformation and sedimentary evolution of the Lake Albert Rift (Uganda, East African Rift System). Mar. Petrol. Geol. 86, 17-37.

Sotnikova, M., Titov, V. 2009. Carnivora of the Tamanian faunal unit (the Azov Sea area). Quatern. Int. 201, 43-52. 
Taylor, M. E. 1974. The functional anatomy of the forelimb of some African Viverridae (Carnivora). J. Morphol. 143 (3), 307-336.

Tessier, F., 1952. Contribution à la stratigraphie et à la paléontologie de la partie Ouest du Sénégal (Crétacé et Tertiaire). Bull. Dir. Mines A. O. F., Dakar 14 (1), 1-267.

Thomas, H., 1980. Les bovidés du Miocène supérieur des couches de Mpesida et de la formation de Lukeino (district de Baringo, Kenya). In: Leakey, R. E. F., Ogot, B. A. (Eds.), Proceedings of the 8th Pan- African Congress of Prehistory and quaternary studies (Nairobi, 1977). Nairobi, pp. 82-91.

Van Couvering, J. A., Delson, E., 2020. African land mammal ages. J. Vert. Paleontol., e1803340 (51 pp.). DOI : 10.1080/02724634.2020.1803340

Valenciano, A., Govender, R. 2020. New insights into the giant mustelids (Mammalia, Carnivora, Mustelidae) from Langebaanweg fossil site (West Coast Fossil Park, South Africa, early Pliocene). PeerJ 8, e9221 DOI 10.7717/peerj.9221

Vautrin, Q., Lihoreau, F., Sambou, B., Thiam, M., Martin, J. E., Tabuce, R., Adnet, S., Lebrun, R., Charruault, A.-L., Sarr, R., Hautier, L., 2019. From limb to fin: an Eocene protocetid forelimb from Senegal sheds new light on the early locomotor evolution of cetaceans. Palaeontology. DOI: 10.1111/pala.12442.

Vrba, E. S., 1997. New fossils of Alcelaphini and Caprinae (Bovidae: Mammalia) from Awash, Ethiopia, and phylogenetic analysis of alcelaphini. Palaeontol. Africana 34, 127-198.

Werdelin, L., 2003. Mio-Pliocene Carnivora from Lothagam, Kenya. In: Leakey, M. G., Harris, J. M. (Eds.), Lothagam: the dawn of humanity in eastern Africa. Columbia University Press, New York, pp. 261-314. 
Werdelin, L., 2010. Chronology of Neogene Mammal localities. In: Werdelin, L., Sanders, W. (Eds), Cenozoic Mammals of Africa. University of California Press, Berkeley, pp. 27-43.

Werdelin, L., Lewis, M. E., 2001. A revision of the genus Dinofelis (Mammalia, Felidae). Zool. J. Linn. Soc. London 132, 147-258.

Werdelin, L., Lewis, M. E., 2020. A contextual review of the Carnivora of Kanapoi. J. Hum. Evol. 140, 102334. DOI: 10.1016/j.jhevol.2017.05.001.

Werdelin, L., Peigné, S., 2010. Carnivora. In: Werdelin, L., Sanders, W. (Eds), Cenozoic Mammals of Africa. University of California Press, Berkeley, pp. 603-657.

Werdelin, L., Sardella, R. J., 2006. The "Homotherium” from Laangebaanweg, South Africa and the origin of Homotherium. Palaeontogr. Abt. A 277, 123-130.

White, T. D., Ambrose, S. H., Suwa, G., Su, D. F., DeGusta, D., Bernor, R. L., Boisserie, J.-R., Brunet, M., Delson, E., Frost, S., Garcia, N., Giaourtsakis, I. X., Haile-Selassie, Y., Howell, F. C., Lehmann, T., Likius, A., Pehlevan, C., Saegusa, H., Semprebon, G., Teaford, M., Vrba, E., 2009. Macrovertebrate Paleontology and the Pliocene Habitat of Ardipithecus ramidus. Science 326, 87-93.

Zazzo, A., Bocherens, H., Brunet, M., Beauvillain, A., Billiou, D., Mackaye, H. T., Vignaud, P., Marrioti, A., 2000. Herbivore paleodiet and paleoenvironmental changes in Chad during the Pliocene using stable isotope ratios of tooth enamel carbonate. Paleobiology 26, 294-309.

Zouhri, S., Benammi, M., Geraads, D., El Boughabi, S. 2017. Mammifères du Néogène continental du Maroc: Faunes, biochronologie et paléobiogéographie. In : Zouhri, S., (Ed.), Paléontologie des vertébrés du Maroc : état des connaissances. Société Géologique de France, Paris, pp. 527-588. 